\title{
Climate-mediated changes to mixed-layer properties in the Southern Ocean: assessing the phytoplankton response
}

\author{
P. W. Boyd ${ }^{1}$, S. C. Doney ${ }^{2}$, R. Strzepek ${ }^{1,3}$, J. Dusenberry ${ }^{2}$, K. Lindsay ${ }^{4}$, and I. Fung ${ }^{5}$ \\ ${ }^{1}$ NIWA Centre for Chemical and Physical Oceanography, Dept. of Chemistry, University of Otago, Dunedin, New Zealand \\ ${ }^{2}$ Marine Chemistry and Geochemistry Department, Woods Hole Oceanographic Institution, Woods Hole, MA 02543, USA \\ ${ }^{3}$ Department of Chemistry, University of Otago, Dunedin, New Zealand \\ ${ }^{4}$ Climate and Global Dynamics, National Center for Atmospheric Research Boulder, CO 80307, USA \\ ${ }^{5}$ Department of Earth \& Planetary Science, Berkeley Institute of the Environment, Berkeley, CA 94720-1250, USA
}

Received: 30 October 2007 - Published in Biogeosciences Discuss.: 23 November 2007

Revised: 6 May 2008 - Accepted: 6 May 2008 - Published: 19 May 2008

\begin{abstract}
Concurrent changes in ocean chemical and physical properties influence phytoplankton dynamics via alterations in carbonate chemistry, nutrient and trace metal inventories and upper ocean light environment. Using a fully coupled, global carbon-climate model (Climate System Model 1.4-carbon), we quantify anthropogenic climate change relative to the background natural interannual variability for the Southern Ocean over the period 2000 and 2100. Model results are interpreted using our understanding of the environmental control of phytoplankton growth rates - leading to two major findings. Firstly, comparison with results from phytoplankton perturbation experiments, in which environmental properties have been altered for key species (e.g., bloom formers), indicates that the predicted rates of change in oceanic properties over the next few decades are too subthe to be represented experimentally at present. Secondly, the rate of secular climate change will not exceed background natural variability, on seasonal to interannual time-scales, for at least several decades - which may not provide the prevailing conditions of change, i.e. constancy, needed for phytoplankton adaptation. Taken together, the relatively subtle environmental changes, due to climate change, may result in adaptation by resident phytoplankton, but not for several decades due to the confounding effects of climate variability. This presents major challenges for the detection and attribution of climate change effects on Southern Ocean phytoplankton. We advocate the development of multi-faceted
\end{abstract}

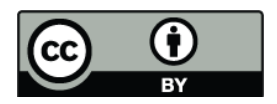

Correspondence to: P. W. Boyd (pboyd@alkali.otago.ac.nz) tests/metrics that will reflect the relative plasticity of different phytoplankton functional groups and/or species to respond to changing ocean conditions.

\section{Introduction}

Climate change impacts ocean biota in many ways, and subsequently biological feedbacks may amplify or dampen any initial climate change signal (Denman et al., 1996; Boyd and Doney, 2003; Fung et al., 2005). These feedbacks arise from both changes in bulk properties (primary production) and in floristics (e.g. diatoms versus coccolithophores) (Boyd and Doney, 2002). Coupled Ocean-Atmosphere Model (COAM) experiments indicate that ocean physical circulation and chemical properties will shift significantly in the coming decades (Sarmiento et al., 1998; Matear and Hirst, 1999). For the Southern (S.) Ocean, surface waters are projected to be warmer and fresher, with increased vertical stratification, shallower mixed-layer depths, reduced sea-ice, and higher oceanic $\mathrm{CO}_{2}$ concentrations. Recent experiments indicate that $\mathrm{S}$. Ocean westerly winds may increase in strength and shift poleward, increasing upwelling (Russell et al., 2006). Alteration of these upper ocean properties will affect phytoplankton dynamics and growth rates directly and indirectly through modifications of vertical nutrient supply, mixedlayer depth, and light climate (Bopp et al., 2001).

Modeling studies have so far focused on simulating the decadal to centennial time-scale effects of climate change on phytoplankton processes, including the construction of biomes (Sarmiento et al., 2004), or the incorporation of more

Published by Copernicus Publications on behalf of the European Geosciences Union. 
biological detail, such as algal functional groups (IglesiasRodriguez et al., 2002; Le Quéré et al., 2005; Litchman et al., 2006) or foodwebs (Legendre and Rivkin, 2005). Recent experimental approaches have concentrated on perturbation studies (weeks to months) of phytoplankton responses to light climate, $\mathrm{CO}_{2}$ or nutrient concentrations, in laboratory cultures (Riebesell et al., 2000), shipboard experiments (Tortell et al., 2002; 2008), mesocosms (DeLille et al., 2005; Riebesell et al., 2007) or $50-200 \mathrm{~km}^{2}$ in-situ patches of the ocean (Boyd et al., 2007).

Two steps are required to explore the relationship between climate-change mediated alteration of ocean properties and the consequent phytoplankton response on intermediary time-scales, i.e. decades - relevant to present experimental and observing system design and to policy makers (Dilling et al., 2003). First, models must provide estimates of future ocean environmental changes, and separate the effects of climate change from intrinsic interannual variability. Currently, COAM's provide one of the few plausible means to do this (Fung et al., 2005; Friedlingstein et al., 2006), and also offer the improved regional predictions needed to predict the rate of climate-mediated change in environmental properties for oceanic provinces.

Second, phytoplankton perturbation experiments must include realistic timescales for the alteration of environmental properties, quantify the potential for physiological plasticity or adaptability of organisms to climate perturbations, and investigate potential synergistic effects due concurrent changes in environmental drivers (e.g. iron and light). Initial experiments used large instantaneous perturbations (from 350 to $750 \mu \mathrm{atm} \mathrm{CO}_{2}$, an IPCC climate-change scenario), resulting in altered calcification rates (Riebesell et al., 2000) or floristic shifts (Tortell et al., 2002). Such striking results represent an upper bound of the effects of climate-change mediated alterations in environmental forcing on phytoplankton processes. However, it is problematic to relate the results from such large, instantaneous perturbations, to the timescales and magnitude of climate change that phytoplankton will actually be exposed to. Phytoplankton can respond to environmental change hours (e.g., algal photoacclimation, Falkowski and LaRoche, 1991), days/weeks (floristic shifts, Riebesell, 1991), to months/years (regime shifts, Boyd and Doney, 2003). This broad range of responses spans the transition from phytoplankton acclimation to adaptation (see Falkowski and LaRoche, 1991).

Here, we compare model estimates of the rates of change in ocean properties due to anthropogenic climate change with results from phytoplankton manipulation experiments, in which these properties have been altered for S. Ocean bloom-forming species (i.e. we recognize the importance of climate effects on higher trophic levels but do not explore this topic here). Moreover, we examine the magnitude and sign of the S. Ocean climate-change and variability signatures, and discuss their implications for phytoplankton acclimation (versus adaptation) to environmental change. These results will inform us of whether the changes in upper ocean properties, and their impact on the biota, will be detectable over the coming decades, and how to design experiments to adequately represent these changes. If we can design such experiments, our findings will lead to improved attribution of the underlying natural and anthropogenic mechanisms driving such changes in the ocean, providing direct tests for the predictions made by numerical models used for future climate projections and policy decisions.

\section{Methods and site selection}

In this study, we focus on the S. Ocean - a region reported to have a disproportionately large impact on global climate (Sarmiento et al., 1998) and which is particularly sensitive to anthropogenic climate warming (e.g. Sarmiento et al., 2004). These waters are characterized by both high macronutrient concentrations (except for silicic acid in subpolar waters) and low rates of aerosol iron supply (Duce and Tindale, 1991; Fung et al., 2000). Macronutrient concentrations in polar waters are predicted to decrease by only ca. $10 \%$ due to climate change (Bopp et al., 2001) and thus the resident phytoplankton are unlikely to be subjected to macronutrient limitation.

Phytoplankton in large regions of the S. Ocean are ironlimited, and climate-change driven alterations of ocean physics will likely impact surface iron concentrations. It is not known whether regional dust deposition rates will increase or decrease due to climate change (Mahowald and Luo, 2003; Moore et al., 2006); likewise predictions of climate-mediated changes in UV irradiance are also inconclusive (Denman et al., 2007). Thus, the impact of changes in aerosol-iron supply or UV irradiance are not considered further here. In these waters, the biogeography of the key algal functional groups is already well defined, for example there are no nitrogen fixers in the S. Ocean (Westberry and Siegel, 2006), and a southwards decrease in coccolithophore abundance is observed (Cubillos et al., 2007).

\subsection{Climate model formulation}

Here, we utilize results from numerical climate simulations generated with the National Center for Atmospheric Research (NCAR) Community Climate System Model (CCSM) (Blackmon et al., 2001). The CSM1.4-carbon model is a fully coupled, global climate-carbon cycle simulation. The model formulation of this version and analyses of its preindustrial equilibrium control solutions are detailed in Doney et al. (2006). The physical climate module consists of coupled atmosphere, land, ocean and ice components, and the exchanges between the model components conserve mass and energy. The ocean and sea-ice model resolution are $3.6^{\circ}$ in longitude and $0.8^{\circ}$ to $1.8^{\circ}$ latitude, with 25 levels in the vertical. The pre-industrial control solutions display stable surface climate and minimal deep ocean drift without 
requiring surface heat or freshwater flux adjustments. The water cycle is closed through a river runoff scheme.

Biogeochemistry in CSM1.4-carbon is simulated with modified versions of the terrestrial model CASA and the OCMIP-2 oceanic biogeochemistry model (Doney et al., 2004; Najjar et al., 2007). In the fully-coupled carbonclimate model, atmospheric $\mathrm{CO}_{2}$ is a prognostic variable and is predicted as the residual after carbon exchanges with the land and ocean. The ocean biogeochemical component includes in simplified form the main processes for the solubility carbon pump, organic and inorganic biological carbon pumps, and air-sea $\mathrm{CO}_{2}$ flux. The prognostic variables transported in the ocean model are phosphate, total dissolved inorganic, dissolved organic phosphorus, dissolved inorganic carbon, alkalinity, and oxygen.

New/export production is computed prognostically as a function of light, temperature, phosphate and iron concentrations. The maximum production as a function of temperature is multiplied by nutrient and light limitation terms. The nutrient term is the minimum of Michaelis-Menten limiting terms for $\mathrm{PO}_{4}$ and $\mathrm{Fe}$ :

$F_{N}=\min \left\{\frac{\mathrm{PO}_{4}}{\mathrm{PO}_{4}+\kappa_{\mathrm{PO}_{4}}}, \frac{\mathrm{Fe}}{\mathrm{Fe}+\kappa_{\mathrm{Fe}}}\right\}$

where $\kappa_{\mathrm{PO}_{4}}$ is $0.05 \mu \mathrm{mol} / \mathrm{L}$ and $\kappa_{\mathrm{Fe}}$ is $0.03 \mathrm{nmol} / \mathrm{L}$ (see later). The light (irradiance) limitation term:

$F_{I}=\frac{I}{I+\kappa_{I}}$,

uses $I$, the solar short-wave irradiance, and a light limitation term $\kappa_{I}\left(20 \mathrm{~W} / \mathrm{m}^{2}\right)$. A fully dynamic iron cycle also has been added including atmospheric dust deposition/iron dissolution, biological uptake, vertical particle transport, and scavenging. In the simulations, as a simplification, dust deposited onto sea-ice is transferred directly to the ocean, with no modification to its properties, such as solubility (see Edwards and Sedwick, 2001).

\subsection{1 st century climate change experiments}

A suite of transient experiments (1820-2100) branching off from the stable, pre-industrial control is conducted by specifying fossil fuel $\mathrm{CO}_{2}$ emissions (Fung et al., 2005). A historical emission trajectory is used for the 19th and 20th centuries and the SRES-A2 "business-as-usual" fossil fuel emission scenario is used for the 21th century. No other greenhouse gases or radiative forcing perturbations are included. Carbon sources associated with anthropogenic land use modification are not included in these experiments. As the other radiative forcing nearly cancel in the 19th and 20th centuries, the climate simulation should be broadly comparable to that observed in the globally averaged sense. However, over the 19th and 20th centuries, land-use modification accounts for approximately $35 \%$ of the cumulative anthropogenic source of atmospheric $\mathrm{CO}_{2}$. The simulated atmospheric $\mathrm{CO}_{2}$ concentration in year 2000, therefore, is $20 \mathrm{ppmv}$ too low compared to observations ( $\sim 367 \mathrm{ppmv})$, lagging about 12 years behind reality. While the model $\mathrm{CO}_{2}$ concentrations cannot be directly matched to calendar years, the overall $\mathrm{CO}_{2}$ temporal trends for the 21th century and the year $2100 \mathrm{CO}_{2}$ concentration $(\sim 765 \mathrm{ppmv})$ are comparable to those from other carbon-climate projections (Friedlingstein et al., 2006).

The climate response for a particular variable $\chi$, denoted as $\Delta \chi(t)$, is computed by differencing the transient climate and control simulations at a particular point in time $t$. The global mean surface air temperature increase $\Delta T_{\text {air }}$ (2100) is $\sim 1.8 \mathrm{~K}$. Friedlingstein et al. (2006) found that CSM1.4carbon is at the lower end of reported climate sensitivities, $\Delta T_{\text {air }} / \Delta \mathrm{CO}_{2}$, relative to several other coupled carbonclimate simulation. In benchmark studies, the transient climate response, i.e. temperature increase at the time of doubling of $\mathrm{CO}_{2}$ where climate models are forced by a $1 \% \mathrm{y}^{-1}$ increase in $\mathrm{CO}_{2}$, is only $1.4 \mathrm{~K}$ for the NCAR CSM1.

Therefore, we have also conducted two additional experiments for the period 2000-2100 where we have artificially increased the climate sensitivity of the CSM1.4-carbon simulation to span the range observed in other COAM's. In these experiments, the atmospheric radiation calculations see a higher effective $\mathrm{CO}_{2}$ concentration than seen by the land or ocean biogeochemistry. Specifically, an atmospheric $\mathrm{CO}_{2}$ perturbation above pre-industrial levels, $\Delta \mathrm{CO}_{2}$, is computed as:

$\Delta \mathrm{CO}_{2}=\mathrm{CO}_{2}^{\text {model }}-\mathrm{CO}_{2}^{\text {preind }}$

The anthropogenic $\mathrm{CO}_{2}$ perturbation is multiplied by a factor of 2 and 4 for cases $\mathrm{A} 2-\mathrm{x} 2$ and $\mathrm{A} 2-\mathrm{x} 4$, respectively, and then add back in the preindustrial concentration to find the $\mathrm{CO}_{2}$ concentration fed to the model atmospheric radiation code:

$$
\begin{aligned}
& \mathrm{CO}_{2}^{\text {radiation }}=2 \times \Delta \mathrm{CO}_{2}+\mathrm{CO}_{2}^{\text {preind }} ; \\
& \mathrm{CO}_{2}^{\text {radiation }}=4 \times \Delta \mathrm{CO}_{2}+\mathrm{CO}_{2}^{\text {preind }}
\end{aligned}
$$

Thus, the climate sensitivity to the anthropogenic $\mathrm{CO}_{2}$ perturbation is effectively enhanced while not directly altering the atmospheric $\mathrm{CO}_{2}$ used for air-sea exchange, $\mathrm{CO}_{2}^{\text {model }}$.

\subsection{Climate change cnalysis}

Climate warming influences marine ecology and biogeochemistry directly through temperature changes and indirectly through changes in ocean circulation (Boyd and Doney, 2003). The climate change signals in the S. Ocean of the CSM1.4-carbon simulation are approximately (though not exactly) zonal, and therefore we have partitioned the $\mathrm{S}$. Ocean into polar and subpolar waters based on frontal structure. We set the boundary as the simulated $130 \mathrm{~Sv}$ stream function that approximates well the boundary between the two water masses in the control simulation. The 


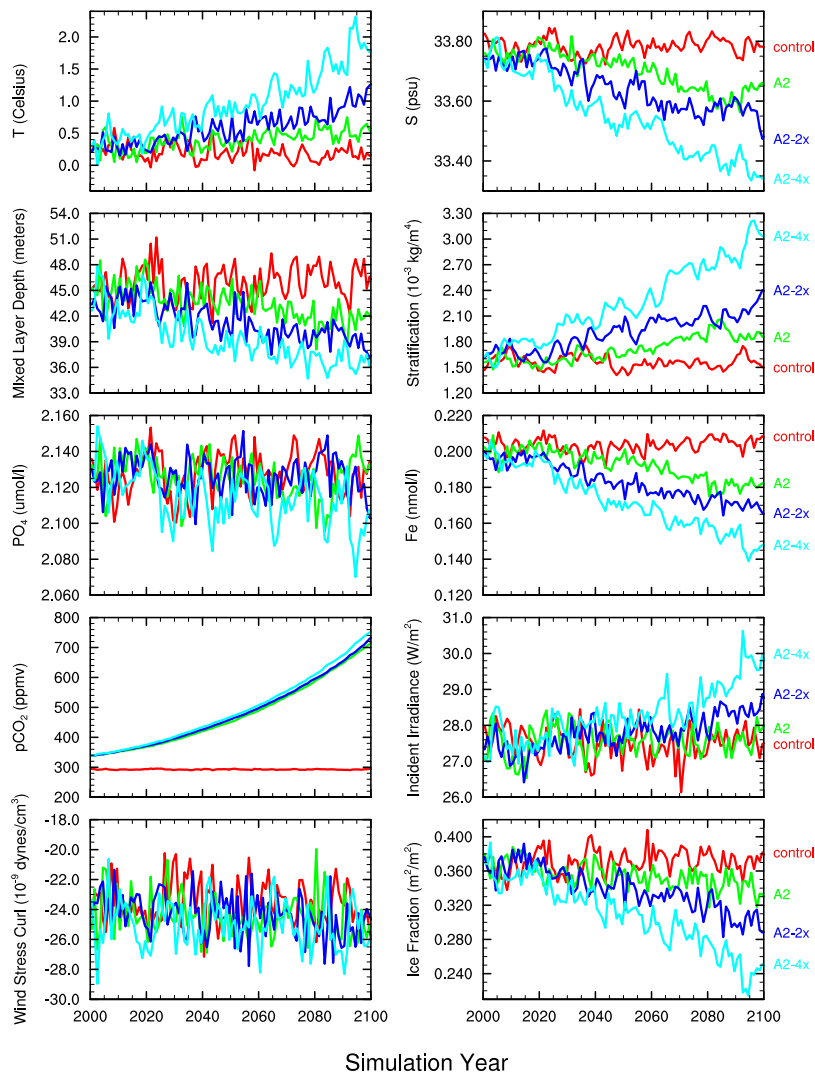

Fig. 1. Annual mean surface water time-series plots (model years 2000-2100) from the control (red) and transient warming simulations (IPCC SRES A2 case green; A2-2x case dark blue; and A2$4 \mathrm{x}$ case light blue) averaged over polar waters from the CSM1.4carbon model. Each panel displays a separate physical or chemical property (temperature, salinity, mixed layer depth, density stratification, phosphate, dissolved iron, $p \mathrm{CO}_{2}$, incident photosynthetically available radiation, upwelling, and ice fraction). The S. Ocean climate change signals in the transient simulations are approximately (though not exactly) zonal, and the model Southern Ocean is partitioned into polar and subpolar waters based on frontal structure, the boundary being set as the simulated $130 \mathrm{~Sv}$ streamfunction that approximates well the boundary between the two water masses.

boundary is prescribed from the control simulation stream function and varies from $60-65 \mathrm{deg}$. $S$ in the Pacific sector to $45-50$ deg. $S$ in the Atlantic sector downstream of the Drake Passage. The model ocean stream function evolves with time under climate change because of two factors, an increase in strength and a poleward contraction of the zonal surface wind maximum in the Southern Ocean associated with a shift toward more positive phase of the Southern Annular Mode (Russell et al., 2006; Le Quéré et al., 2007; Lovenduski et al., 2007). The effects of the two processes partially counteract and the lateral shift for the $130 \mathrm{~Sv}$ streamline is minimal. In our analysis the subpolar/polar boundary is not allowed to vary through time, which would complicate the comparison with time because it would confound temporal and geograph-
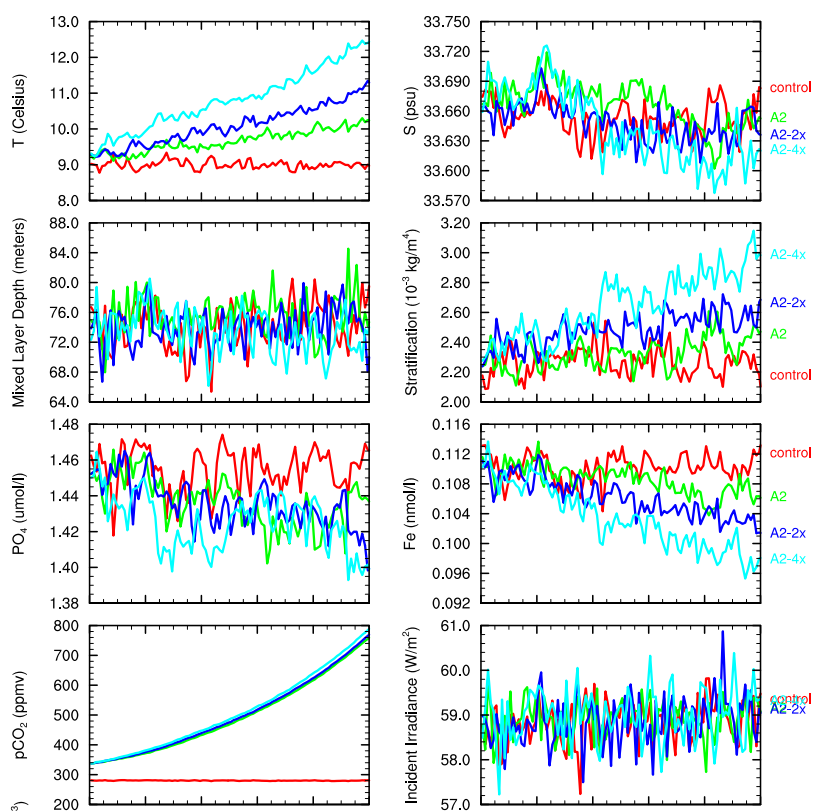

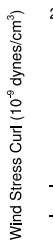
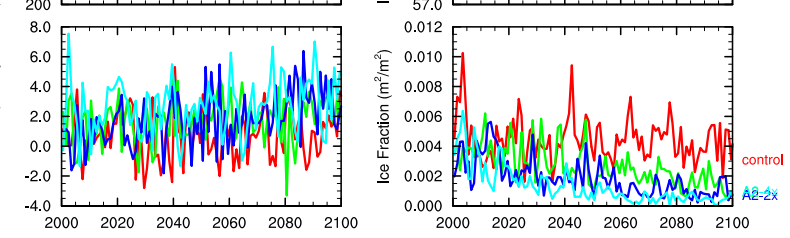

Simulation Year

Fig. 2. The same as Fig. 1 but for subpolar waters.

ical variations. Climate trends are significant only if they differ substantially from the drift of the control simulation, if non-zero, and are larger than the intrinsic interannual variability of the model. For the spatial maps, a Student's t-test is used to measure the significance of the differences between the two decades relative to the simulated interannual variability. Regions where $\Delta \chi$ (2020-2029 minus 2000-2009) is less than the standard deviation of $\chi$ for the decade 2000 2009 based on a student's $t$-test are masked out.

\subsection{Phytoplankton perturbation experiments}

Methods for laboratory culture experiments where light climate and/or trace metal concentrations were altered are presented in Appendix A. Due to the high ambient macronutrient concentrations in surface polar waters no macronutrient perturbation experiments were performed. For the methods used in other studies synthesized in Table 1b, please refer to these publications. 
Table 1a. Comparison for S. Ocean sub-polar and polar waters of the relative rate of (a) climate-change mediated alteration of annual-mean ocean properties that influence phytoplankton processes expressed as change per decade compared with; (b) A summary of the range of conditions for each ocean property under which manipulation experiments have been conducted on either key polar bloom-forming species, or natural polar assemblages. The climate change rates in a) are estimated from a suite of fully coupled CSM 1.4-Carbon simulations by spatially averaging over the subpolar or polar domains (boundary defined by the $130 \mathrm{~Sv}$ stream function contour) and averaging over the period 2000 and 2100. The model ranges correspond with the simulations with varying model climate sensitivities to atmospheric $\mathrm{CO}_{2}$ perturbations. The model estimated rms variability in annual-mean, spatial averaged ocean properties due to natural climate variability is included for reference. nd denotes uncertainty over sign of change (Mahowald et al., 2005). Due to the paucity of data on the effects of environmental manipulations on sub-polar phytoplankton this summary focuses only on polar waters. However, see studies by Riebesell et al. (2007) and Hutchins et al. (2001).

\begin{tabular}{|c|c|c|c|c|}
\hline Property & $\begin{array}{l}\text { Rate of change } \\
\text { Subpolar waters } \\
\text { per decade }\end{array}$ & $\begin{array}{l}\text { Rate of Change } \\
\text { Polar waters } \\
\text { per decade } 1\end{array}$ & $\begin{array}{l}\text { RMS variability for } \\
\text { subpolar waters due } \\
\text { to natural climate } \\
\text { variability }\end{array}$ & $\begin{array}{l}\text { RMS variability for } \\
\text { polar waters } \\
\text { due to natural climate } \\
\text { variability }\end{array}$ \\
\hline Temperature deg. $\mathrm{C}$ & +0.10 to +0.36 & +0.03 to +0.14 & 0.11 & 0.13 \\
\hline Salinity psu & -.003 to -.007 & -.014 to -.042 & 0.017 & 0.027 \\
\hline Mixed layer depth m & +0.3 to -0.8 & -0.3 to -0.8 & 3.0 & 2.0 \\
\hline Stratification $\mathrm{kg} / \mathrm{m}^{4} \times 10^{-4}$ & +0.16 to +0.67 & +0.28 to +1.49 & 0.94 & 0.77 \\
\hline Surface $\mathrm{PO}_{4} \mu \mathrm{mol} / 1$ & -.001 to -.005 & +.001 to -.004 & .012 & 0.012 \\
\hline Surface $\mathrm{Fe} n \mathrm{nmol} / 1 \times 10^{-3}$ & -0.32 to -1.30 & -1.89 to -5.58 & 1.80 & 3.85 \\
\hline$p \mathrm{CO}_{2} \mathrm{ppmv}$ & +33.9 to +44.6 & +37.4 to +41.0 & 0.8 & 1.2 \\
\hline \multirow[t]{4}{*}{ Light climate } & Surf. PAR & Surface PAR 0.02 to & Surface PAR $0.49 \mathrm{~W} / \mathrm{m} 2$ & Surface PAR $0.43 \mathrm{~W} / \mathrm{m} 2$ \\
\hline & 0.03 to $0.05 \mathrm{~W} / \mathrm{m} 2$ & $0.23 \mathrm{~W} / \mathrm{m} 2$ & Water column PAR $^{\mathrm{a}}$ & Water column PAR $^{\mathrm{a}}$ \\
\hline & Water column PAR ${ }^{\mathrm{a}}$ & Water column PAR $^{\mathrm{a}}$ & 0.04 to $0.05 \mathrm{~W} / \mathrm{m} 2$ & 0.05 to $0.07 \mathrm{~W} / \mathrm{m} 2$ \\
\hline & 0.004 to $0.006 \mathrm{~W} / \mathrm{m} 2$ & 0.003 to $0.005 \mathrm{~W} / \mathrm{m} 2$ & & \\
\hline Aerosol dust & nd & nd & nd & nd \\
\hline Ice fraction & -.0003 to -.0004 & -.003 to -.013 & 0.0015 & 0.013 \\
\hline
\end{tabular}

a surface mixed-layer light climate was derived using mixed layer depth and chlorophyll concentration (as a proxy of light attenuance) as detailed in Boyd et al. (2007).

$1 \mathrm{~W} / \mathrm{m} 2 \sim 0.4$ mol quanta $\mathrm{m}^{-2} \mathrm{~d}^{-1}$ from Cloern et al. (1995).

\section{Results}

\subsection{Model simulations}

The CSM1.4-carbon results are broadly similar to other COAM simulations that exhibit surface warming of Southern Ocean waters in response to anthropogenic climate change. While the anthropogenic warming signal is quite clear in the CSM1.4-carbon A2 case by the end of the 21st century, the warming trend earlier in the century is less apparent because of natural variability, particularly over shorter time-spans of a couple of decades relevant to the establishment of ocean observing systems. In the low climate sensitivity A2 case, the decadal mean sea surface temperature (SST) in the subpolar region increases by $+0.10 \mathrm{~K} /$ decade for a 20 -year period (model years 2020-2029 minus 2000-2009) (Figs. 13; Table 1a). For comparison the root mean squared (rms) variability of the subpolar mean SST on interannual scales is $0.11 \mathrm{~K}$. Given a sampling duration of two to three decades, therefore, the anthropogenic SST warming trend is thus detectable, though somewhat marginally, above the natural interannual variability for the subpolar region. The secular warming trend is less pronounced in polar waters closer to
Antarctica in the A2 case, about $+0.03 \mathrm{~K} /$ decade, and the climate change temperature signal does not clearly exceed natural variability (rms $0.13 \mathrm{~K}$ ) until roughly model year 2060 .

The anthropogenic warming trends are larger for the A2$\mathrm{x} 2$ and $\mathrm{A} 2-\mathrm{x} 4$ higher climate sensitivity cases. The decadal subpolar warming trend in $\mathrm{A} 2-\mathrm{x} 4(+0.36 \mathrm{~K} /$ decade $)$, for example, is more than 3 times the warming trend in the $\mathrm{A} 2$ case. For the A2- $\mathrm{x} 4$ case, the polar temperature rise $(+0.14 \mathrm{~K} /$ decade) becomes significant relative to natural variability on the decadal scale, and the secular warming signal becomes detectable by model year 2020. Surface temperature is one of the few COAM variables for which we can compare the simulated surface ocean trends against the observed historical Southern Ocean record over the last several decades. This can be done due to the relatively large climate warming signal compared to interannual variability, and because of the relatively comprehensive in situ and satellite data coverage for temperature. But even for temperature, the historical observation data set (particularly for subsurface waters) has significant gaps in the Southern Ocean, complicating model evaluation (Doney et al., 2007). Further, because the coupled model has its own internally-driven, nonlinear climate variability that is often out of phase with the 
Table 1b. Polar waters

\begin{tabular}{|c|c|c|c|c|}
\hline Property & $\begin{array}{l}\text { Phaeocystis antarc- } \\
\text { tica }\end{array}$ & $\begin{array}{l}\text { Fragillariopsis } \\
\text { kerguelenis }\end{array}$ & Proboscia alata & $\begin{array}{l}\text { Diatom species } \\
\text { or natural populations }\end{array}$ \\
\hline Temperature & No data & No data & No data & $\begin{array}{l}\text { See text } \\
\text { Natural populations }{ }^{\mathrm{a}}\end{array}$ \\
\hline Nutrient supply (Si) & Non-siliceous ${ }^{b}$ & No data & No data & $\begin{array}{l}\text { See text } \\
\text { Diatom bloom }\end{array}$ \\
\hline Dissolved iron (DFe) & $K_{m}=0.1 \mathrm{nM}^{\mathrm{d}}$ & $K_{m}=0.57^{\mathrm{e}}$ & No data & $K_{m}=0.006$ to $>1 \mathrm{nM}^{\mathrm{e}}$ \\
\hline $\begin{array}{l}\text { Iron } \quad \text { bioavailability } \\
\left(\mathrm{Fe}^{\prime}\right)^{\mathrm{f}}\end{array}$ & $0.32 \mathrm{aM}-25.4 \mathrm{fM}$ & $3.5 \mathrm{aM}$ to $0.27 \mathrm{pM}$ & $0.64 \mathrm{aM}$ to $51.3 \mathrm{fM}$ & $3.5 \mathrm{aM}$ to $0.27 \mathrm{pM}^{\mathrm{g}}$ \\
\hline $\mathrm{CO}_{2}$ & $\mathrm{CCM}$ present & CCM present & $\mathrm{CCM}$ present & $\mathrm{CCM}^{\mathrm{h}}$ \\
\hline Light climate & $\begin{array}{l}\text { Rapid photo- } \\
\text { acclimation (hours } \\
40-400 \mu \text { mol quanta } \\
\mathrm{m}^{-1} \mathrm{~s}^{-1} \text { ) }\end{array}$ & Rapid photo-acclimation & Rapid photo-acclimation & $\begin{array}{l}\text { See text } \\
\text { Rapid photo-acclimation }\end{array}$ \\
\hline $\begin{array}{l}\text { Dissolved iron and light } \\
\text { climate }\end{array}$ & $\begin{array}{l}K_{m} \text { decreased from } \\
0.35 \mathrm{nM} \mathrm{Fe} \text { at low } \\
\text { light to } 0.1 \mathrm{nM} \text { at } \\
\text { high light } \mu \text { max } \\
\text { (i.e. Fe replete) at } \\
60 \mu \mathrm{E}\end{array}$ & See text & See text & $\begin{array}{l}\text { Low light results in both } \\
\text { increases and decreases } \\
\text { in } \mathrm{Fe} \text { requirements de- } \\
\text { pending on spp. (Raven et } \\
\text { al., 1999) }\end{array}$ \\
\hline $\begin{array}{l}\text { Other synergistic ef- } \\
\text { fects } \\
\text { a) Temperature and } \\
\text { light }\end{array}$ & & & & $\begin{array}{l}\text { See text, (Tilzer et al. } \\
1986 \text { ) }\end{array}$ \\
\hline b) Light and CCM's & No data & No data & No data & $\begin{array}{l}\text { See text, } \\
\text { Beardall and Gior- } \\
\text { dana }(2002)\end{array}$ \\
\hline $\begin{array}{l}\text { c) Temperature and } \mathrm{Fe} \\
\text { supply }\end{array}$ & & & & $\begin{array}{l}\text { See text, natural popula- } \\
\text { tions, Feller et al. (2001) }\end{array}$ \\
\hline
\end{tabular}

a Tilzer et al. (1986), Scotia Sea and Bransfield Strait, light-saturated and light-limited photosynthetic rates and their relationship with temperature.

b altered N:P ratios for $P$. antarctica relative to diatoms (more efficient $\mathrm{N}$ uptake per unit $\mathrm{P}$ (Arrigo et al., 1998).

${ }^{\mathrm{c}}$ Nelson et al. (2001) study of silica uptake kinetics along a meridional gradient in silicic acid ranging from $<5$ in the north to $45 \mu \mathrm{M}$ in the South.

d Sedwick et al. (2007), effects of iron and light on the growth of natural populations of colonial Phaeocystis antarctica, Ross Sea.

e Timmermans et al. (2001), $K_{m}$ (dissolved iron concentration versus growth rate (DFe for $1 / 2 \mu$ max)) for a range of diatoms including Chaetoceros brevis ( $K_{m}$ 0.006) to Actinocyclus (1.14),

f Timmermans et al. (2001) used dissolved iron as they could not define Fe bioavailability, and we have used Fe' as a proxy for bioavailability.

$\mathrm{g}$ lab culture studies on Southern Ocean polar isolate Eucampia Antarctica (Strzepek, unpublished data).

h CCM's denote the presence of an inorganic Carbon Concentrating Mechanism. All polar species so far examined ( 9 diatoms and $P$. antarctica) have all exhibited CCM's (Tortell et al., 2007).

interannual variability of the real system, we are restricted to comparing long-term secular trends in the model and observations.

With those caveats in mind, the long-term spatial warming patterns in the model are broadly consistent with historical observations (Fig. 3). Like the model, observations exhibit higher surface warming in the Southern Ocean subtropical and subpolar bands than in polar waters, where there has either been no statistical trend or in some cases weak cooling rather than warming (Smith and Reynolds, 2005; Trenberth et al., 2007). Averaged zonally, the historical (1955-2003) upper ocean warming trends in the S. Ocean are 0.0 to +0.025 $\mathrm{K} /$ decade for polar waters and +0.025 to $+0.10 \mathrm{~K} /$ decade for subpolar waters (Levitus et al., 2005; Bindoff et al., 2007). Using subsurface float data from the 1990s relative to historical hydrography, Gille (2002) reports mid-depth (700$1000 \mathrm{~m}$ ) warming rates of $0.04+/-0.01 \mathrm{~K} /$ decade averaged across $35 \mathrm{~S}$ to $65 \mathrm{~S}$ and rates as high as $0.08+/-0.02 \mathrm{~K} /$ decade in the core of the subantarctic front. The highest rates of subsurface ocean warming are comparable to the observational 
atmospheric surface warming rates for the Southern Ocean region of $0.13+/-0.06 \mathrm{~K} /$ decade.

The CSM coupled model warming rates for the last half of 20th century (in model years 2000-2009 minus 19501959 adjusting for the atmospheric $\mathrm{CO}_{2}$ delay) are in good agreement with the observed warming. As predicted by other coupled simulations, the model predicted warming rates tend to accelerate in the 21 st century, with the simulated warming rates over the next 20 year period of subpolar +0.10 to $+0.31 \mathrm{~K} /$ decade; polar +0.03 to +0.17 ) (Figs. $1-3$, Table 1 ).

Both anthropogenic warming and interannual climate variability influence the spatial pattern of regional surface ocean anomalies. The right-hand column of Fig. 3 displays spatial maps for difference in simulated surface property between model decade 2020-2029 minus decade 2000-2009 for the A2 case. In the model simulation a zonal band of warmer SSTs occurs in the subtropics and subpolar waters, and a large area of cooling is found in the polar Atlantic sector. The Atlantic regional cooling illustrates an important point that on sub-basin scales interannual climate can slow or even reverse for individual sampling periods the anthropogenic warming impacts that are apparent at larger basin and global scales. To focus on the longer term trends in the decadal difference maps in the right-hand column, areas are masked with white if the observed temporal differences are small relative to rms interannual variability.

The magnitude of the interannual variability ( $r m s$ of annual means) in model surface properties is displayed in the left-hand column of Fig. 3. For SST, the regions of maximum interannual variability occur along frontal boundaries, in particular for the example shown in Fig. 3 in Pacific sector along roughly $60 \mathrm{deg}$. S and in the Atlantic sector east of South Georgia Island near $30 \mathrm{deg}$. W. The Southern Annular Mode (SAM) is a significant contributor to ocean interannual variability in the Southern Ocean that reflects the strength of the atmospheric pressure low over the Antarctic continent and the high in the subtropics and subpolar region. A positive SAM occurs with an intensification of both the Antarctic low and subtropical high, resulting in field observations and models in stronger westerly winds, increased upwelling, cooler SSTs in polar waters and subpolar central Pacific and warmer SSTs elsewhere in the Southern Ocean (e.g., Lovenduski et al., 2007). The CSM1.4 model decadal SST anomaly patterns with warming of the subpolar zone and neutral or cooling of the polar zone are similar to those observed for a shift to a more positive SAM. The SST patterns along with the increased surface winds and upwelling in the simulation are consistent with the argument that anthropogenic warming in the S. Ocean will be expressed, in part, through a projection onto an increasing SAM (Le Quéré et al., 2007). The other clear anthropogenic signal is, as would be expected, the increase in surface water $p \mathrm{CO}_{2}$ due to the rise in atmospheric $\mathrm{CO}_{2}$ in the transient simulation. North of $\sim 55^{\circ} \mathrm{S}$, the $\Delta p \mathrm{CO}_{2}$ (here transient - control not air - water) tracks the increase in the atmosphere, and absolute values are $650-800$ ppmv by 2100 . Poleward of this boundary, the surface water $p \mathrm{CO}_{2}$ increases but not as rapidly as the atmosphere due to ice cover and the upwelling of older waters from below; average levels are only 500-580 ppmv by 2100 .

For most of the other physical and biogeochemical factors in the CSM1.4 A2 case, however, the climate change signal is smaller than or comparable to natural variability on the decadal time-scale (2020-2029 minus 2000-2009), making it difficult to identify anthropogenic signatures. Further, on the sub-basin and basin scale there are regions exhibiting both positive and negative changes over decadal time periods. This is illustrated in the spatial difference maps (decade 2020-2029 minus decade 2000-2009) for case A2 displayed in Fig. 3. For example, the differences maps of mixed layer depth and stratification show no distinct patterns of the climate warming signal evident later in the century - reduced mixed layer depth in polar waters due to freshening, increased mixed layer depth in subpolar waters due to stronger winds, and increased vertical stratification in both polar and subpolar waters due to surface freshening and warming, respectively (see temporal trends in Figs. 1 and 2).

The large white regions in both maps indicate model points where the decadal changes in mixed layer depth or stratification are so small that they are not statistically significant relative to the model interannual variability. The simulation also exhibits nearly as many areas of decreasing stratification (green/blue) as increasing stratification (yellow/orange). Indeed, based on the time-series plots averaged over the subpolar and polar regions, a definitive basin-scale climate warming signal or elevated stratification for the A2 case would not be observable until roughly 2040 (polar) and 2070 (subpolar); the threshold for detecting shallower mixed layer depth is also about 2040 for polar waters and is not found by the end of the 21 st century in subpolar waters.

The anthropogenic climate signals become more distinct for the in the A2-x2 and A2-x4 cases, with increased climate sensitivity for the following properties: decreasing polar sea surface salinity, increased subpolar and polar stratification, decreased subpolar and polar surface dissolved iron concentrations, poleward shift and increased strength in polar upwelling, and increased polar surface ocean irradiance due to decreased ice fraction. In higher climate sensitivity cases, the date at which the anthropogenic signal is detectable from the natural background also occurs earlier in time, often by decades.

The climate response for surface phosphate and iron concentrations reflect the balance between changing upwelling and mixing of high nutrient, subsurface waters from below (source), residence time of surface water, and biological export production (sink). The rate of change of surface nutrient concentrations $\chi$ is given by: 


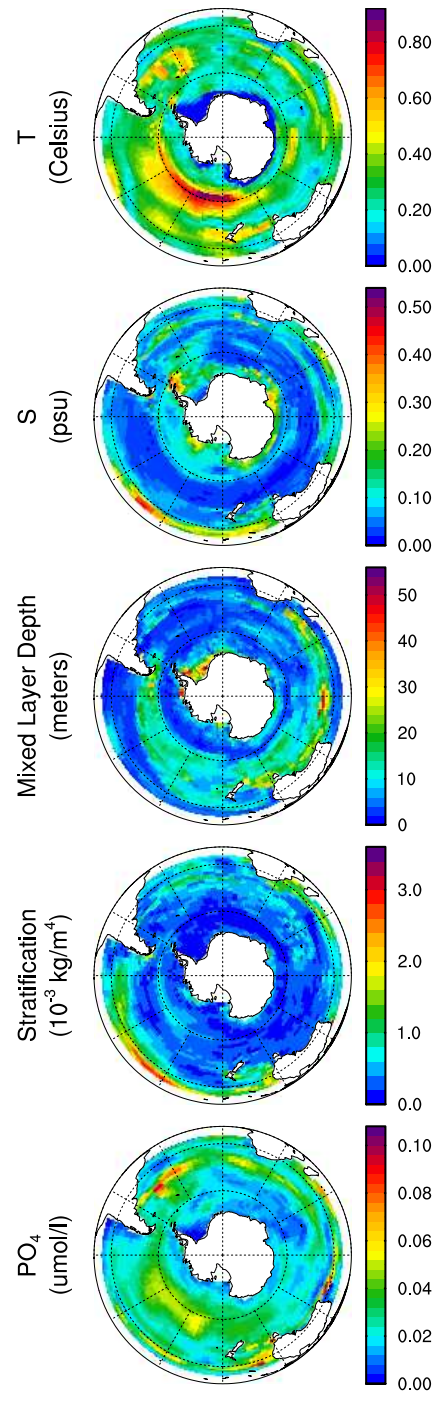

Std. Deviation

$$
\begin{aligned}
& \frac{\partial \chi}{\partial t}+\nabla_{h} \cdot(\boldsymbol{u} \chi)-\nabla_{H} \cdot\left(K_{H} \nabla_{H} \chi\right)+\boldsymbol{u}_{Z} \frac{\partial}{\partial z} \chi \\
& -\frac{\partial}{\partial z} K_{Z} \frac{\partial}{\partial z} \chi=\text { RHS }_{\text {bio }}
\end{aligned}
$$$$
\left(\begin{array}{c}
0 \\
3 \\
3
\end{array}\right.
$$$$
\left(\begin{array}{ccc}
0.60 \\
0.40 \\
0.20 \\
0.00 \\
0.20 \\
0.40
\end{array}\right.
$$$$
\left(\begin{array}{cc}
1 \\
4 \\
4
\end{array}\right.
$$$$
\text { (1) }
$$$$
\text { a }
$$

$\Delta$ (Property) time-scales.

Fig. 3. Spatial maps of S. Ocean interannual variability and anthropogenic climate response from the CSM1.4-carbon transient IPCC SRES A2 simulation. The left column shows the natural interannual variability, expressed as the standard deviation of the annual means from a 10 year segment of the control simulation; the right column shows the climate response expressed as the temporal difference over a 20 year time period, the average of model years 2020-2029 minus the average of model years 2000-2009. Each row displays a separate surface water physical or chemical property (temperature, salinity, mixed layer depth, density stratification, phosphate, dissolved iron, $p \mathrm{CO}_{2}$, incident photosynthetically available radiation, upwelling, and ice fraction). Regions where the absolute value of the temporal difference is less than one standard error of the difference between the means are masked out.

where the physical transport is partitioned into horizontal and vertical advection and mixing terms; the biological surface uptake and subsurface remineralization are grouped into a single biogeochemical right hand side term $\mathrm{RHS}_{\text {bio. }}$ Increased stratification and shallower mixed layers tend to decrease the mixing $K_{Z}$, while shifts in wind patterns may tend to increase upwelling $u_{Z}$ while decreasing surface resident

In CSM1.4, surface nutrient concentrations tend to stay constant or decrease. Phosphate exhibits a small decline from $40-60^{\circ} \mathrm{S}$ on average and is constant from $60^{\circ} \mathrm{S}$ to the pole. Phosphate concentrations remain large relative to $\kappa_{\mathrm{PO}_{4}}$ and do not become limiting to organic matter production and export (Eq. 1). There are more notable decreases in surface dissolved iron concentrations, -5 to $-10 \mathrm{pmol} / \mathrm{l}$ relative to mean levels of $80-160 \mathrm{pmol} / 1$ for $40-60^{\circ} \mathrm{S}$ and -20 to $-30 \mathrm{pmol} / \mathrm{l}$ relative to mean levels of $150-240 \mathrm{pmol} / \mathrm{l}$ south of $60^{\circ} \mathrm{S}$. For comparison, the model half saturation constant for algal iron limitation for biological organic matter export $\kappa_{\mathrm{Fe}}$ is $30 \mathrm{pmol} / \mathrm{l}$ (i.e. towards the lower end of published values) The trends in surface macro- and micro-nutrients, along with the light/mixed layer and SST in turn impact the downward export flux (Eqs. 1 and 2). Integrated over the entire S. Ocean (including the subtropics), simulated organic matter export remains about the same, though it tends to shift poleward due to the southward migration in the band of deep winter mixing and the expansion of subtropical conditions. In the subpolar region, downward export increases by $\sim 10-15 \%$ in October and July while it tends to decrease further south.

The trends predicted for climate change of warmer waters, shallower mixed layers, and thus higher light levels, and lower nutrient and dissolved iron concentrations in the mixed layer (Table 1a) are consistent with the change in seasonal properties from spring to summer conditions (Table 2). The one exception to this is oceanic $\mathrm{CO}_{2}$ concentrations, which are predicted to rise (Table 1a), akin to the progression from summer to winter conditions (Table 2). This new matrix of environmental trends that combine the spring to summer progression (light, nutrients, metals) and summer to winter progression $\left(\mathrm{CO}_{2}\right)$ is something that phytoplankton will not have encountered since the geological past (for example, the Paleocene-Eocene Thermal Maximum; Gibbs et al., 2006). The seasonal amplitude in key oceanic properties in both polar and sub-polar waters is considerably greater than the magnitude of the predicted changes in these properties due to climate change (Table 1a c.f. Table 2), however there is insufficient resolution in the simulations to investigate how this seasonal amplitude will be influenced by climate change. 
Table 2a. Polar waters.

Summary of seasonal ranges for (a) the polar waters of the Ross Sea; and (b) for subpolar waters S of New Zealand (i.e. S of the STF and N of the SAF).

\begin{tabular}{lll}
\hline Mixed layer Property & Seasonal range & Reference \\
\hline Incident irradiance & $6-56 \mathrm{~mol} \mathrm{quanta} \mathrm{m}^{-2} \mathrm{~d}^{-1}$ & Hiscock et al. (2001) \\
Mixed layer depth & $<40 \mathrm{~m}$ to $>100 \mathrm{~m}$ & Measures and Vink \\
Nitrate & 34 to $<20 \mu \mathrm{mol} \mathrm{L}^{-1}$ & Gordon et al. (2000) \\
Silicic acid & 74 to $66 \mu \mathrm{mol} \mathrm{L}^{-1}$ & Gordon et al. (2000) \\
tCO & 2140 to $2260 \mu \mathrm{mol} \mathrm{Kg}^{-1}$ & Gordon et al. (2000) \\
Dissolved iron & 0.22 to $0.1 \mathrm{nmol} \mathrm{L}^{-1}$ & Measures and Vink (2001) \\
\hline
\end{tabular}

Table 2b. Subpolar waters.

\begin{tabular}{lll}
\hline Mixed layer Property & Seasonal range & Reference \\
\hline Incident irradiance & $13-45 \mathrm{~mol} \mathrm{quanta} \mathrm{m}^{-2} \mathrm{~d}^{-1}$ & Boyd (unpublished data) \\
Mixed layer depth & $<30 \mathrm{~m} \mathrm{to}>120 \mathrm{~m}^{-1}$ & Nodder et al. (2005) \\
Nitrate & 15 to $<6 \mu \mathrm{mol} \mathrm{L}^{-1}$ & Sherlock et al. (2006) \\
Silicic acid & 0.9 to $2.5 \mu \mathrm{mol} \mathrm{L}^{-1}$ & S. Pickmere (unpublished data) \\
$\mathrm{tCO}_{2}$ & 2060 to $2110 \mu \mathrm{mol} \mathrm{Kg}^{-1}$ & K. Currie (unpublished data) \\
Dissolved iron & 0.12 to $0.07 \mathrm{nmol} \mathrm{L}^{-1}$ & Boyd et al. (2005) \\
\hline
\end{tabular}

Broadly similar physical climate response patterns have been found in other 21 st century coupled ocean-atmosphere climate simulations, though as mentioned above the CSM1.4-carbon model tends to be at the low end of the range in terms of climate sensitivity to atmospheric $\mathrm{CO}_{2}$ perturbations. Using a series of empirical diagnostic calculations, Sarmiento et al. (2004) examined the potential marine ecological responses to climate warming using physical data from six different coupled climate model simulations, including a variant of CSM 1. Averaged over the models, climate warming led to a contraction of the highly productive marginal sea ice biome and expansion of the subpolar gyre biome and low productivity, permanently stratified subtropical gyre biome in the S. Ocean. Vertical stratification tends to increase, which would be expected to decrease nutrient supply everywhere but also increase the growth season in some high latitude regions (Sarmiento et al., 2004). They did not investigate the magnitude of upwelling other than in defining the boundaries and shifts in biomes. Sarmiento et al. (2004) suggest that chlorophyll will increase in the open S. Ocean, due primarily to the retreat of and changes at the northern boundary of the marginal sea ice zone; but chlorophyll may tend to decrease adjacent to the Antarctic continent due primarily to freshening within the marginal sea ice zone. Estimated primary productivity generally will increase mainly as a result of warmer temperatures.

The climate-change driven trends in surface water properties in the Southern Ocean do not occur independently, and synergistic effects need to be accounted for in phytoplankton responses. One approach that has been advocated is to use biological responses to interannual physical/chemical variability as an analogue for climate change (Boyd and Doney, 2002); but this line of reasoning depends upon the character of the interannual physical/chemical variability being similar to that of climate change, including property-property relationships. Table 3 presents property-property linear regressions (regression slopes and correlation coefficients) for surface ocean temperature, mixed layer depth and nutrient anomalies for both interannual variability (annual means from control simulation) and anthropogenic climate change (A2 case, decadal means of 2020-2029 minus 2000-2009; Fig. 3). For natural interannual variability, there are statistically significant correlations of warmer SSTs, shallower mixed layers and lower surface nutrient concentrations; surface iron and phosphate also are well correlated. The patterns differ considerably for climate change. The signs of the climate change and interannual variability SST-surface nutrient correlations are the same, but the regression slopes

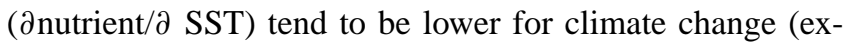
cept for polar $\partial \mathrm{Fe} / \partial \mathrm{SST}$ ). Under climate change, the correlations of subpolar mixed layer anomalies to other properties are weak and not statistically significant. In polar waters, the variations of mixed layer depth to temperature are larger, and there is a fourfold reduction in the magnitude of the $\partial \mathrm{PO}_{4} / \partial \mathrm{Fe}$ slope relative to the same value for interannual variability. Overall, the property-property correlation 
Table 3. A summary of the co-variation of physical and biogeochemical property anomalies due to climate change. Each entry in the table reports the linear regression coefficients (slope and correlation coefficient) for the spatial anomalies from the CCSM1.4-carbon simulation for either interannual variability (monthly values from 100 years of control simulation) or anthropogenic climate change (found from differencing the A2 case decadal average maps 2020-2029 minus 2000-2009; Fig. 3). Separate regressions are computed for the subpolar and polar domains. No slope is reported for regressions where the absolute value of the correlation coefficient is less than 0.2. MLD denotes mixed layer depth.

\begin{tabular}{|c|c|c|c|c|c|}
\hline \multicolumn{2}{|c|}{ Interannual Variability } & \multicolumn{2}{|c|}{ Subpolar } & \multicolumn{2}{|c|}{ Polar } \\
\hline X Variable & Y Variable & Slope Y/X & Correlation $\mathrm{r}$ & Slope Y/X & Correlation $\mathrm{r}$ \\
\hline T (deg. C) & $\operatorname{Hmix}(\mathrm{m})$ & -9.24 & -0.33 & -5.29 & -0.36 \\
\hline T (deg. C) & $\mathrm{PO}_{4}(\mu \mathrm{mol} / \mathrm{l})$ & -0.057 & -0.75 & -0.054 & -0.76 \\
\hline T (deg. C) & $\mathrm{Fe}(\mathrm{nmol} / \mathrm{l})$ & -0.033 & -0.39 & -0.036 & -0.68 \\
\hline $\operatorname{MLD}(\mathrm{m})$ & $\mathrm{PO}_{4}(\mu \mathrm{mol} / \mathrm{l})$ & 0.0014 & 0.52 & 0.0028 & 0.59 \\
\hline $\operatorname{MLD}(\mathrm{m})$ & $\mathrm{Fe}(\mathrm{nmol} / \mathrm{l})$ & .00067 & 0.68 & 0.0028 & 0.58 \\
\hline $\mathrm{Fe}(\mathrm{nmol} / \mathrm{l})$ & $\mathrm{PO}_{4}(\mu \mathrm{mol} / \mathrm{l})$ & 4.02 & 0.68 & 2.33 & 0.80 \\
\hline \multicolumn{2}{|c|}{ Climate Change } & \multicolumn{2}{|c|}{ Subpolar } & \multicolumn{2}{|c|}{ Polar } \\
\hline X Variable & Y Variable & Slope Y/X & Correlation $\mathrm{r}$ & Slope Y/X & Correlation $\mathrm{r}$ \\
\hline T (deg. C) & $\operatorname{Hmix}(\mathrm{m})$ & $\mathrm{n} / \mathrm{a}$ & 0.11 & -8.49 & -0.42 \\
\hline T (deg. C) & $\mathrm{PO}_{4}(\mu \mathrm{mol} / \mathrm{l})$ & -0.030 & -0.76 & -0.030 & -0.45 \\
\hline T (deg. C) & $\mathrm{Fe}(\mathrm{nmol} / \mathrm{l})$ & -0.008 & -0.75 & -0.086 & -0.77 \\
\hline MLD (m) & $\mathrm{PO}_{4}(\mu \mathrm{mol} / \mathrm{l})$ & $\mathrm{n} / \mathrm{a}$ & -0.05 & 0.0016 & 0.50 \\
\hline MLD (m) & $\mathrm{Fe}(\mathrm{nmol} / \mathrm{l})$ & $\mathrm{n} / \mathrm{a}$ & -0.04 & 0.0048 & 0.67 \\
\hline $\mathrm{Fe}(\mathrm{nmol} / \mathrm{l})$ & $\mathrm{PO}_{4}(\mu \mathrm{mol} / \mathrm{l})$ & 4.75 & 0.76 & 0.54 & 0.53 \\
\hline
\end{tabular}

analysis suggested that interannual variability is only a weak analogue for climate change with respect to synergistic and non-linear interactions across multiply variables.

3.2 Polar phytoplankton responses to environmental perturbations

Physiological responses of both laboratory-cultured species and natural assemblages to altered environmental conditions are summarized (Table 1b). The range of conditions used in experiments is readily compared to predicted changes in these properties due to climate change (Table 1). Tilzer et al. (1986) investigated temperature effects on photosynthetic performance in cells from the Scotia Sea and Bransfield Strait. They expressed temperature effects using $Q_{10}$ - a commonly used temperature coefficient which provides a measure of the rate of change of algal physiology due to a $10^{\circ} \mathrm{C}$ increase in temperature. Light-saturated photosynthesis $\left(P_{b} \max \right)$ increased significantly with increasing temperatures from $-1-.5^{\circ} \mathrm{C}$ to $8^{\circ} \mathrm{C}$, c.f. Table 1a). The greatest enhancement of $P_{b}$ max occurred between $-1.5^{\circ} \mathrm{C}$ and $2^{\circ} \mathrm{C}\left(Q_{10}>4\right)$, but decreased at temperatures of $>2$ to $5^{\circ} \mathrm{C}$, ( $Q_{10}$ of 2.6), and at $>5^{\circ} \mathrm{C}$ was negligible. This response illustrates the high sensitivity of polar organisms to temperature (Clarke, 2003). Studies on coastal phytoplankton indicate that a $1{ }^{\circ} \mathrm{C}-2^{\circ} \mathrm{C}$ warming around the Antarctic Peninsula might not alter photosynthetic rates, but could channel more photosynthetically fixed carbon into DOC (Moran et al., 2006). Also in these waters, Moline et al. (2004) reported floristic shifts from diatoms to chrysophytes, between 1991 and 1996, associated with warmer temperatures and a consequent reduction in salinity. Thus, warming can both directly and indirectly impact phytoplankton processes, and probably influences polar (e.g. ice melt, $Q_{10}$ ) waters to a greater extent than sub-polar regions.

Few laboratory studies have been conducted on how altering nutrient supply will impact the physiology of polar/subpolar phytoplankton (Boyd, 2002). However, natural gradients in surface nutrient concentrations $(<5$ to $45 \mu \mathrm{mol} \mathrm{Si} \mathrm{L}{ }^{-1}$ ) such as during a southwards progressing bloom along the $170^{\circ} \mathrm{W}$ meridian (i.e. Pacific sector; Nelson et al., 2001) provides estimates of how the silicic acid uptake kinetics of diatoms are altered by changing upper ocean conditions. Such a lateral silicic acid gradient is much greater than the relative change in nutrient concentrations due to climate change (see $\mathrm{PO}_{4}$, Table 1a). Nelson et al. (2001) observed no clear trend in affinity for silicic acid by diatoms (i.e. $K_{S}$ ) with latitude or silicic acid concentration, however there was an apparent seasonal progression - with a lower affinity for silicic acid evident over time. Critically, information in Nelson et al. on which species were present is lacking, and thus it is not known whether temporal/spatial shifts in floristics influenced these trends in uptake kinetics. Thus, their findings have limited value in predicting how diatoms, at the species level, might respond to predicted reductions in nutrient concentrations (Table 1a). 
Manipulation of either light climate or $\mathrm{CO}_{2}$ concentrations appear to have relatively little effect on polar species. Cultured polar phytoplankton can rapidly acclimate to a two- to three-fold range of irradiances on a timescale of hours to days (R. Strzepek, unpublished data) Such photoacclimation has been widely reported for non-polar species (Falkowski and LaRoche, 1991). The maximum growth rate of Phaeocystis antarctica occurs at $\sim 60 \mu$ mol quanta $\mathrm{m}^{-2} \mathrm{~s}^{-1}$ (Table $1 \mathrm{~b}$ ), and declines rapidly at lower irradiances, whereas at higher than saturating irradiances their growth rate decreases but at a much slower rate (R. Strzepek, unpublished data). This trend is also observed for cultured polar diatoms (R. Strzepek, unpublished data). Predictions in Table 1a indicate that increased mean irradiances, due to a shoaling of the mixed layer, will occur with climate change. However, this increase is probably too subtle to result in a detectable alteration of phytoplankton growth rates.

Some phytoplankton species have Carbon Concentrating Mechanisms (CCM's) which permit them to compensate, via active intracellular accumulation, for the large difference (ranging from 5- to 20-fold) between the $\mathrm{CO}_{2}$ concentration in the surrounding waters with that within their cellular machinery (Kaplan et al., 1991). Beardall and Giordana (2002), reviewed phytoplankton CCM's and suggest that rising ocean $\mathrm{CO}_{2}$ concentrations may impact the performance of groups with (diatoms) and without (chrysophytes) CCM's. Rost et al. (2003) examined representative bloomformers (diatom, coccolithophorid, and Phaeocystis) acclimated to 36-1800 ppmv $\mathrm{CO}_{2}$. They reported major differences in the ability of each species to both regulate carbon acquisition and in the efficiency of carbon acquisition. In the most comprehensive study of CCM's in S. Ocean biota to date, Tortell et al. (2008) present evidence of the presence of inorganic CCM's (i.e. i.e. cells transporting $\mathrm{HCO}_{3}^{-}$and utilizing carbonic anhydrase to catalyze $\mathrm{HCO}_{3}$ dehydration to $\mathrm{CO}_{2}$ ) for each of ten polar species, including Phaeocystis antarctica, and Fragilariopsis kerguelensis, they investigated. This widespread presence of CCM's is evident for mixed assemblages in the subpolar Bering Sea (Martin et al., 2006) and NE Pacific (Tortell et al., 2006). Thus, it is difficult to predict whether any particular species would have a selective advantage to utilize $\mathrm{CO}_{2}$ at the predicted higher concentrations (Table 1a).

In contrast to light climate and $\mathrm{CO}_{2}$ concentrations, changes in dissolved iron concentrations had a pronounced effect on the growth rate (i.e. $K_{m}$, see Table 1 b) of different polar species in culture, regardless of whether iron supply was expressed as dissolved iron or bioavailable/free $\mathrm{Fe}$ (Table 1b). Although there are difficulties in defining what constitutes bioavailable iron, that confound the comparison of model parameterizations with observational data, the range of dissolved iron concentrations (that set half the maximum algal growth rate) in Table $1 \mathrm{~b}$ is considerably greater than predicted changes in dissolved iron concentrations due to climate change (Table 1a). Polar diatoms generally exhib- ited higher values of $K_{m}$ than for Phaeocystis antarctica (Table $1 \mathrm{~b}$ ), indicative of a greater sensitivity to future decreases in dissolved iron predicted by the model (Table 1a).

There are few studies of the synergistic effects due to simultaneous limitation (or its alleviation) of algal growth by multiple environmental factors. Takeda (1998) reported increased silicification rates at low, relative to high, dissolved iron concentrations in two cultured polar diatoms: silicification will be altered by both iron and silicic acid supply, two properties that will be influenced by climate change (Table 1a). Beardall and Giordano (2002) concluded that factors which may impact algal CCM's include $\mathrm{CO}_{2}$ concentrations, temperature and also UV-B radiation. In SW Atlantic polar waters, Feller et al. (2001) reported that both SST and low dissolved iron concentrations limited growth rates of resident phytoplankton. These studies all point to the complex interactions between environmental properties that will be altered concurrently by climate change (Table 1a).

Other synergistic effects include iron and irradiance, and studies of iron/light interactions have reported up to threefold reductions in $K_{m}$ for colonial Phaeocystis antarctica following transfer from low to high light conditions (Sedwick et al., 2007; Table 1b). Strzepek (Table 1b) observed that, for three cultured Thalassiosira species and Phaeocystis antarctica (non-colonial), the greatest effect of iron-limitation is observed at higher growth irradiances, i.e. $\mu / \mu \max$ is lower at higher light levels (where $\mu$ denotes Fe-limited and $\mu$ max represents Fe-replete growth rates). His findings differ from reports that low irradiance exacerbate algal iron requirements (Timmermans et al., 2001; Maldonado et al., 1999); this disparity may result from the use of different cultured species, or different methodologies (acclimated versus nonacclimated; i.e. Timmermans et al.; cultures). Raven et al. (1999) suggest that low light results in both increases and decreases in algal iron requirements depending on species.

\section{Discussion}

\subsection{Climate-change mediated alteration of ocean properties - response of the phytoplankton}

Table 1a summarises the concurrent changes in factors that influence phytoplankton processes. The predicted decadal rates of change for all properties, including the largest climate change signal $-\mathrm{CO}_{2}\left(3-4 \mathrm{ppmv} \mathrm{yr}^{-1}\right)$, are unprecedented on geological timescales (Denman et al., 2007); however they are small compared with experimental perturbations used to date (in both laboratory studies and mesocosms instantaneous perturbations of $>100 \mathrm{ppmv}$ are common, e.g. Riebesell et al., 2000; 2007; Tortell et al., 2008). The studies, listed in Table $1 \mathrm{~b}$, provide valuable insights into what environmental factors control phytoplankton physiology. However, as they are all based on instantaneous and relatively large perturbation of environmental conditions, they 
will be of limited value for predicting the algal response to climate change. Such perturbations provide no information on the potential for physiological plasticity for different phytoplankton groups or species. Such information is needed to gauge whether different groups will adapt to the more gradual trends in environmental properties that will occur due to climate change. Representation of these gradual environmental changes, for example, would require slow increases in $\mathrm{CO}_{2}$ of 3-4 $\mathrm{ppmv} \mathrm{yr}^{-1}$ for six months to several years. Such an experiment, albeit with a small change in $\mathrm{CO}_{2}$, might permit extrapolation of the observed response of different species to perturbation, and would refine the approaches used previously (i.e. large instantaneous perturbations, Riebesell et al., 2000). But artifacts due to bottle or mesocosm containment (see Beninca et al., 2008) will likely confound any biological response to the climate change signal. Thus, we must explore alternative means to capture, in some way, the effects of relatively slow rates of climate-mediated change on ocean properties.

Although the predicted rate of change in each ocean property is too subtle to be represented experimentally, it is possible that the potential multiplicative impact of synergistic effects (i.e. simultaneous limitation of algal growth by several factors) could be reproduced experimentally. Here, we consider iron and light. The model simulations predict lower dissolved iron concentrations and slightly higher underwater light levels (Table 1a), which may result, for some algal species (Raven et al., 1999), in greater simultaneous limitation of phytoplankton growth rate by iron and light (i.e. the greatest displacement of growth rates from their maximum, Phaeocystis antarctica, see results). However, any amplification of the biological signal via a greater phytoplankton physiological response to multiple factors (and their alteration by climate-change) may be countered by increased uncertainty, due to increased complexity, in predicting how phytoplankton dynamics will change when multiple properties are considered. Therefore, the combined effect of simultaneous alteration of these factors is currently beyond prediction.

4.2 Climate change versus variability - implications for biological adaptation

In addition to climate change, other sources of variability will occur concurrently, including climate variability (e.g. SOI Southern Oscillation Index), seasonal gradients, and episodic (weeks) perturbations (e.g. dust storms). Although the effects of climate variability and climate change can be deconvolved in simulations (Fig. 3), these overlying effects will potentially confound the detection and attribution of trends in the biota as they respond to climate change. For the coming decades, the magnitude of change in oceanic properties due to climate variability is much larger than the long-term, secular climate change trend. In some cases, particularly for the low climate sensitivity A2 case, there is not a noticeable shift in the extremes for several more decades. Moreover the di- rection of the change may differ between climate change and variability (Table 1a; see Sarmiento, 1993). Thus, it is possible that secular climate change will only induce significant biological effects when the magnitude of the environmental perturbations (and floristic changes) exceed background natural variability on seasonal to interannual time-scales. Such an inflection point might lead to detectable responses by the biota, as species commence selection for eco-types (Medlin, 1994) more suited to changing conditions where the sign of change is constant over time (i.e. adaptation rather than acclimation, Falkowski and LaRoche et al., 1991); as opposed to changing conditions with no prevailing trend due to fluctuations in the dominant control on the alteration of ocean properties (seasonal gradients, climate variability, secular climate change).

The assessment of the relative ability of different phytoplankton species to resist change and/or adapt to climate change may be a valuable tool to be used in conjunction with other experimental approaches such as Collins and Bell'(2002). Resilience in phytoplankton, i.e. the maintenance of a given state when subject to disturbance (sensu, Carpenter and Cottingham, 1997), may result from an inbuilt tolerance of a wide range of environmental conditions (Margalef, 1978;). Physiological plasticity, defined here as the ability to acclimate (i.e. physiological processes, Falkowski and LaRoche, 1991) to, and therefore gradually adapt (i.e. evolutionary processes, Falkowski and LaRoche, 1991) to, changing and/or new conditions, is akin to resilience. As stated earlier, such adaptation - over longer timescales - presupposes the need for a clear and sustained change in environmental conditions.

It is now established that oceanic organisms can adapt physiologically, over timescales of years, to pronounced environmental changes. Such adaptability has been observed in corals, in response to warming temperature causing "bleaching, which successfully responded by recruiting "new" algal symbionts (Baker et al., 2004). Furthermore, a laboratory study recently tracked physiological and morphological changes in Clamydomonas resulting from one thousand generations at elevated $\mathrm{CO}_{2}$ concentrations. They reported smaller cell size and a broader ranges in rates of photosynthesis and respiration resulting from this two year laboratory culture study (Collins and Bell, 2004). Thus, the relationship between the physiological plasticity of phytoplankton and the rate of change of environmental drivers is a key factor (and unknown) in determining whether such altered environmental forcing will result in floristic shifts and/or altered physiology.

There appears to be several key factors that control the degree of physiological plasticity in phytoplankton: a) the underlying survival strategy of organisms - specialist (k) or generalist (r) (Margalef, 1978); b) genetic variability and phytoplankton species and c) the timing of the emergence in the ocean of different groups and/or species in the geological past. Generalist species tend to dominate in systems close 
to resource limitation such as oligotrophic waters (Reynolds, 1984). Therefore, the low iron supply that characterises much of the S. Ocean may favour $\mathrm{r}$ over $\mathrm{k}$ species, and the mandala (i.e. conceptual representation of environmental conditions and phytoplankton responses) of Margalef (1978) should be modified to include trace metals. Physiological plasticity will be driven by both geno- and pheno-typic characteristics, for example the success of bloom-forming phytoplankton may be due to their genetic variability, such that the genetic variability (i.e. ability to adapt to changing conditions) within a bloom may be greater than that between blooms (Medlin et al., 1996). However little is known about whether genetic diversity between different species will result in a corresponding degree of physiological or ecological 'variability' (Iglesias-Rodriguez et al., 2006). The two year (i.e. 1000 generations) study of Clamydomonas by Collins and Bell (2004) presented evidence of accumulated mutations in genes affecting the $\mathrm{CCM}$, after at elevated $\mathrm{CO}_{2}$ concentrations, that were translated into physiological changes.

It is now evident that the physiological characteristics of different phytoplankton groups were strongly influenced by the ambient oceanic conditions when they emerged over time since the Proterozoic era. The trace metal requirements of different algal groups (e.g. high iron for diatoms) may have been set by the redox state of the ocean at the time of their emergence (Saito et al., 2003; Quigg et al., 2003; Falkowski et al., 2004). This may also be the case for coccolithophorids which evolved across a range of oceanic $\mathrm{CO}_{2}$ conditions (Langer et al., 2006a). Experiments by Langer et al. (2006a, b) have shown that two species have different calcification responses to a gradient in $\mathrm{CO}_{2}$ concentrations; Coccolithus pelagicus (no change with increasing $\mathrm{CO}_{2}$ concentrations) and Calcidiscus leptoporus (maximum rate at present day $\mathrm{CO}_{2}$ concentrations). Recently, IglesiasRodriguez et al. (2008) presented evidence from laboratory culture studies that calcification rates for Emiliania huxleyi increased above 490 ppmv $\mathrm{CO}_{2}$, and significant increases in coccolith mass from deep-ocean core records for the last 200 years). Significantly, these responses differ from those reported by Riebesell et al. (2000) for Emiliania huxleyi. Thus, the ability to respond (i.e. adaptation) to changing trace metal or $\mathrm{CO}_{2}$ conditions may have been imprinted genetically during their evolutionary history.

\subsubsection{Scenarios for phytoplankton responses - implications} for detection versus attribution

Consideration of the interplay of climate change with the degree of physiological plasticity within phytoplankton groups or species leads to three scenarios: 1) ecosystems are very "plastic" (Langer et al., 2006b) - with no or limited changes in community structure as the resident cells can adapt to climate change over years to decades; 2 ) the climate change signal simply results in a poleward migration of "fixed" biomes (Sarmiento et al., 2004); 3) conditions change sufficiently that a "new" community or ecosystem arises that has no analogue in current ocean (Boyd and Doney, 2003). These scenarios provide conceptual frameworks to examine the detection and attribution of such shifts.

Phytoplankton within "plastic" ecosystems could adjust their physiological properties rather than alter species composition. Such a response is particularly difficult to detect and monitor, and would require a time-series of physiological experiments on natural populations. This approach has been advocated in terrestrial ecosystems, via the integration of observations on natural climate gradients (e.g. spatial change in light) with climate change experiments (Dunne et al., 2004). The second scenario - climate-mediated shifts in biomes will probably be easier to detect and monitor, for example remote-sensing to monitor shifts in coccolithophore distributions (due to climate variability) was used successfully in the Bering Sea (Merico et al., 2003). Migration of the boundaries of biomes is less likely in the S. Ocean where both the geographical isolation and strong meridional frontal boundaries (Smetacek and Nichol, 2005) minimize the impact of phenotypic adaptation (Medlin, 1994) and results in well-defined biomes. Thus, unanticipated floristic shifts will be conspicuous, and thus should be readily detected.

In contrast, for scenario three - unanticipated shifts to a new phytoplankton assemblage, may not be readily detected, unless they have a different bio-optical signature that results in fortuitous detection by satellite sensors (Ciotti et al., 2002; Alvain et al., 2006; Raitsos et al., in press).

\subsubsection{The magnitude of climate change versus the subse-} quent phytoplankton response

Our model predictions point to subtle changes in environmental properties that influence phytoplankton processes over the coming decades in the S. Ocean. How will such changes influence the response of the resident phytoplankton? Based on our limited knowledge, such as from long term time-series observations (Smayda et al., 2005), or case studies of the effects of climate variability (Chavez et al., 1999), adaptation is the most likely algal response to climate change in these waters $(\mathrm{N}$. B. this does not take into account top-down foodweb effects). The extension of phytoplankton biomes is unlikely due to the strong circumpolar features in the S. Ocean, and the magnitude of change in oceanic properties is probably insufficient in the next two decades to result in pronounced floristic shifts. Such dramatic shifts, for example from low picophytoplankton stocks to diatom blooms, are mediated by climate variability in the Equatorial Pacific (Chavez et al., 1999), but are driven by large and rapid changes in environmental conditions (i.e. a sixfold increase in vertical iron supply between years, c.f. Table 1a). As such they are generally poor proxies for climate change. However, such adaptation to climate change, and its detection, in the next twenty years will be confounded by other sources of climate variability. 
4.2.3 Approaches to investigate phytoplankton responses to climate change

No single approach is sufficient to address this pressing issue. Due to the difficulties in conducting manipulation experiments that could represent the predicted rates of change in oceanic properties, multi-faceted tests for assessment of change should be developed (e.g. Peterson and Keister, 2003). A nested suite of perturbation experiments including laboratory (mechanistic understanding of physiological pathways; see MacIntyre and Cullen, 2005) and shipboard experiments (physiology of phytoplankton assemblages), mesocosms or mesoscale perturbations (floristic shifts and their underlying mechanisms), and novel ecosystem modeling techniques (Follows et al., 2007) are required. Climatechange perturbation studies in terrestrial systems reveal the major influence of experimental duration (of up to 5 years) on the outcome of the perturbation (Walther, 2007), but extrapolating such conclusions to the ocean is problematic due to differences in the turnover of plant biomass between land (years) and ocean (days) (Falkowski et al., 1998).

Boyd and Doney (2002) advocated the use of perturbation experiments, monitoring, and biogeography to investigate the effects of climate change and the subsequent feedbacks. Their approach required both global (incorporation of greater biological complexity) and regional (data interpretation based on a scheme of provinces). Our study provides further insights into what degree of biological complexity is required. The use of evolutionary history in conjunction with assessment of the paleo-environment under which phytoplankton groups/species emerged is a powerful tool to interpret the results from perturbation experiments (Langer et al., 2006a, b). Thus, the three-stranded approach of Boyd and Doney (2002) must also incorporate a nested suite of perturbations, and information on phytoplankton plasticity.

\section{Appendix A}

\section{Algal manipulation experiments - culturing techniques}

Lab culture experiments - using recent isolates (2004) from the HNLC S. Ocean which have been maintained in low metal media - key algal species include bloom forming diatoms such as Fragilariopsis kerguelensis, Chaetoceros spp., Proboscia alata, and the other key bloom former in the open Southern Ocean - Phaeocystis antarctica. P. antarctica was isolated in the austral summer of 2001 at $61^{\circ}$ $20.80 \mathrm{~S}, 139^{\circ} 50.60 \mathrm{E}$ from a single colony. The culture was rendered axenic by treatment with antibiotics (Cottrell and Suttle, 1993), which was confirmed by epifluorescent microscopy on culture subsamples treated with DAPI according the recommendation of Kepner and Pratt (1994). Phytoplankton were grown in the artificial seawater medium Aquil (Price et al., 1988) prepared in Milli-Q water (Milli- pore Corp.). The seawater, containing the major salts, was enriched with $10 \mu \mathrm{mol} \mathrm{L}^{-1}$ phosphate, $100 \mu \mathrm{mol} \mathrm{L}^{-1}$ silicate and $300 \mu \mathrm{mol} \mathrm{L}^{-1}$ nitrate. Trace metal contaminants were removed from the medium and nutrient enrichment stock solutions using Chelex 100 ion exchange resin (Sigma, St. Louis, MO) according to the procedure of (Price et al., 1988). Media were enriched with filter-sterilized $(0.2 \mu \mathrm{m}$ Gelman Acrodisc PF) EDTA-trace metal and ESAW vitamin solutions (Harrison et al., 1980). Free trace metal ion concentrations, in the presence of $10 \mu \mathrm{mol} \mathrm{L}^{-1}$ EDTA as the chelating agent, were as follows (-log free metal ion concentration=pMetal): $\mathrm{pCu} 13.79, \mathrm{pMn} 8.27, \mathrm{pZn} 10.88$, and $\mathrm{pCo}$ 10.88. These concentrations were calculated using the chemical equilibrium computer program MINEQL (Westall et al., 1976) with the thermodynamic constants reported in Ringbom (1963). Selenite and molybdate were added at $10^{-8}$ and $10^{-7} \mathrm{~mol} \mathrm{~L}^{-1}$ respectively. The salinity and initial $\mathrm{pH}$ of the medium was $35 \mathrm{psu}$ and $8.17 \pm 0.04(n=13)$, respectively. All cultureware and plastics that came in contact with cultures were rigorously cleaned and sterilized according to the procedures detailed in Maldonado and Price (1996) to minimize trace metal and bacterial contamination. Media were prepared and cultures were sampled in a sterile Class 100 laminar flow bench.

Solitary cells of $P$. antarctica were grown in semicontinuous batch cultures at $4 \pm 1 \_C$ in continuous light at 7 intensities $(3,20,30,60,100,400$ and $570 \mu \mathrm{mol}$ photons $\mathrm{m}^{-2} \mathrm{~s}^{-1}$ ) obtained using fluorescent bulbs (12 W Sylvania) attenuated with neutral density screening, and measured with a 4 pi quantum meter (model QSL-2101, Biospherical Instruments, San Diego, CA). The basal medium contained $1.8 \pm 0.1 \mathrm{nmol} \mathrm{L}^{-1}$ iron contamination $(n=6)$, which was determined electrochemically ( $C L E-A C S V$, competitive ligand equilibrium- adsorptive cathodic stripping voltammetry). At each growth irradiance, cultures were grown in a variety of media that differed in their total Fe concentration, and Fe-organic complex type and concentration. High iron medium was prepared by adding $2.6 \mathrm{nmol} \mathrm{L}^{-1}$ of pre-mixed, filter-sterilized FeEDTA $(1: 1)$ which, due to the photolability of FeEDTA complexes, corresponds to a range of measured inorganic iron concentrations $\left([\mathrm{Fe}]=53-111 \mathrm{pmol} \mathrm{L}^{-1}\right.$ from 3 to $570 \mu \mathrm{mol}$ photons $\mathrm{m}^{-2} \mathrm{~s}^{-1}$ ) as determined with the sulfoxine method. Cultures were also grown in Aquil medium containing either 10 or $100 \mu \mathrm{mol} \mathrm{L}^{-1}$ of EDTA containing and no added iron. To induce Fe stress, $2 \mathrm{nmol} \mathrm{L}^{-1}$ of $\mathrm{Fe}$ was added as a complex with 4,40 or $400 \mathrm{nmol} \mathrm{L}^{-1}$ of the terrestrial siderophore desferrioxamine B mesylate (DFB, Sigma) to Aquil medium containing $10 \mu \mathrm{mol} \mathrm{L}^{-1}$ of EDTA to chelate the other trace metals. Stock DFB solutions $\left(0.1-10 \mathrm{mmol} \mathrm{L}^{-1}\right)$ were prepared in Milli-Q water, and were $0.2 \mu \mathrm{m}$ filter sterilized after dissolution. The Fe was premixed with the DFB before addition to the media as previously described (Maldonado and Price, 1999). The media with the added FeDFB complex were allowed to equilibrate overnight. As $P$. antarctica maintained maximum 
growth rates in Aquil medium containing no added $\mathrm{Fe}$ and either 10 or $100 \mu \mathrm{mol} \mathrm{L}^{-1}$ of EDTA, we assumed that the $1.8 \mathrm{nmol} \mathrm{L}^{-1} \mathrm{Fe}$ contamination in the basal medium was bioavailable. Therefore the FeDFB ratios in these media were 3.8:4, 3.8:10, and 3.8:100 $\mathrm{nmol} \mathrm{L}^{-1}$, respectively.

Specific growth rates $\left(d^{-1}\right)$ were calculated from leastsquares regressions of $\ln$ in vivo fluorescence versus time during the exponential growth phase of acclimated cul- tures. During experiments to explore the physiological plasticity of Fragilariopsis kerguelensis, Proboscia alata, and P. antarctica to iron availability and light climate, Fe treatments ranging from 19.4 to Fe:DFB 4:400 nM, Growth PFD from 5 to 400 mol photons $\mathrm{m}^{-2} \mathrm{~s}^{-1}$.

Acknowledgements. Philippe Tortell (UBC) kindly provided unpublished data from a recently submitted manuscript. This manuscript was considerably improved by insightful comments from two anonymous reviewers. S.C.D. was supported in part by the WHOI Ocean and Climate Change Institute and a grant from the National Science Foundation (NSF ATM06-28582). Computational resources were provided by the NCAR Climate Simulation Laboratory. The National Center for Atmospheric Research is sponsored by the US National Science Foundation. P.W.B. was supported by the NZ FRST Coasts and Oceans OBI.

Edited by: A. Bricaud

\section{References}

Alvaina, S., Moulin, C., Dandonneau, Y., Loisel, H. Bre'on, F.-M.: A species-dependent bio-optical model of case I waters for global ocean color processing, Deep-Sea Res. I, 53, 917-925, 2006.

Arrigo, K. R., Robinson, D. H., Worthen, D. L., Dunbar, R. B., DiTullio, G. R., VanWoert, M., and Lizotte, M. P.: Phytoplankton community structure and the drawdown of nutrients and $\mathrm{CO}_{2}$ in the Southern Ocean, Science, 283, 365-367, 1999.

Baker, A. C., Starger, C. J., McClanahan, T. R., and Glynn, P. W.: Corals' adaptive response to climate change, Nature, 430, 741, 2004.

Beardall, J. and Giordano, M.: Ecological implications of microalgal and cyanobacterial $\mathrm{CO}_{2}$ concentrating mechanisms, and their regulation, Funct. Plant Biol., 29, 335-347, 2002.

Beninca, E., Huisman, J., Heerkloss, R., D. Jo“hn, K.D., Branco, P., Van Nes, E.H., Scheffer, M., and Ellner, S. P.: Chaos in a long-term experiment with a plankton community, Nature, 451, 822-828, doi:10.1038/nature06512, 2008.

Bindoff, N. L., Willebrand, J., Artale, V., Cazenave, A., Gregory, J., Gulev, S., Hanawa, K., LeQuéré, C., Levitus, S., Nojiri, Y., Shum, C. K., Talley L. D., and Unnikrishnan A.: Observations: Oceanic Climate Change and Sea Level, in: Climate Change 2007: The Physical Science Basis, Contribution of Working Group I to the Fourth Assessment Report of the Intergovernmental Panel on Climate Change, edited by: Solomon, S., Qin, D., Manning, M., Chen, Z., Marquis, M., Averyt, K. B., Tignor, M. and Miller, H. L., Cambridge University Press, Cambridge, United Kingdom and New York, NY, USA, 2007.
Blackmon, M., Boville, B., Bryan, F., Dickinson, R., Gent,P., Kiehl, K., Moritz, R., Randall, D., Shukla, J., Solomon, S., Bonan, G., Doney, S., Fung, I., Hack, J., Hunke, E., Hurrell, J., Kutzbach, J., Meehl, J., Otto-Bliesner, B., Saravanan, R., Schneider, E. K., Sloan, L., Spall, M., Taylor, K., Tribbia J., and Washington, W.: The Community Climate System Model, Bull. Amer. Meteorol. Soc., 82, 2357-2376, 2001.

Bopp, L., Monfray, P., Aumont, O., Dufresne, J.-L., Le Treut, H., Madec, G., Terray L., and Orr, J. C.: Potential impact of climate change on marine export production, Global Biogeochem. Cy., 15, 81-99, 2001.

Boyd, P. W.: Environmental factors controlling phytoplankton processes in the Southern Ocean, J. Phycol, 38, 844-861, 2002.

Boyd, P. W. and Doney, S. C.: Modelling regional responses by marine pelagic ecosystems to global climate change, Geophys. Res. Lett., 29(16), 53-1 to 53-4, doi:10.1029/2001GL014130, 2002.

Boyd, P. and Doney, S. C.: The impact of climate change and feedback process on the ocean carbon cycle, in: Ocean Biogeochemistry, edited by: Fasham, M., Springer, 157-193, 2003.

Boyd, P. W., Law, C. S., Hutchins, D. A., Abraham, E. R., Croot, P. L., Ellwood, M., Frew, R.D., Hadfield, M., Hall, J., Handy, S., Hare, C., Higgins, J., Hill, P., Hunter, K. A., LeBlanc, K., Maldonado, M. T., McKay, R. M., Mioni, C., Oliver, M., Pickmere, S., Pinkerton, M., Safi, K., Sander, S., SanudoWilhelmy, S. A., Smith, M., Strzepek, R., Tovar-Sanchez, A., and Wilhelm, S. W.: FeCycle: Attempting an iron biogeochemical budget from a mesoscale $\mathrm{SF}_{6}$ tracer experiment in unperturbed low iron waters, Global Biogeochem. Cy., 19, GB4S20, doi:10.1029/2005GB002494, 2005.

Boyd, P. W., Jickells, T., Law, C. S., Blain, S., Boyle, E. A., Buesseler, K. O., Coale, K. H., Cullen, J. J., de Baar, H. J. W., Follows, M., Harvey, M., Lancelot, C., Levasseur, M., Owens, N. P. J., Pollard, R., Rivkin, R. B., Sarmiento, J., Schoemann, V. Smetacek, V., Takeda, S., Tsuda, A., Turner, S., and Watson, A. J.: Mesoscale iron enrichment experiments 1993-2005: Synthesis and future directions, Science, 315, 612-617, 2007.

Carpenter, S. R. and Cottingham, K. L.: Resilience and restoration of lakes, Conservation Ecology (online): available from the Internet: http://www.consecol.org/vol1/iss1/art2/, 1997.

Ciotti, A. M., Cullen, J. J. and M. R. Lewis, M. R.: Assessment of the relationships between dominant cell size in natural phytoplankton communities and the spectral shape of the absorption coefficient, Limnol. Oceanogr., 47, 404-417, 2002.

Clarke, A.: Costs and consequences of evolutionary temperature adaptation, Trends Ecol. Evol., 18, 573-581, 2003.

Cloern, J. E., Grenz, C., and Vidergar-Lucas, L.: An empirical model of the phytoplankton chlorophyll : carbon ratio-the conversion factor between productivity and growth rate, Limnol. Oceanogr., 40, 1313-1321, 1995.

Collins, S. and Bell, G.: Phenotypic consequences of 1000 generations of selection at elevated $\mathrm{CO}_{2}$ in a green alga, Nature, 431, 566-569, 2004.

Cottrell, M. T. and Suttle, C. A.: Production of Axenic Cultures of Micromonas-Pusilla (Prasinophyceae) Using Antibiotics, J. Phycol., 29, 385-387, 1993.

Cubillos, J. C., Wright, S. W., Nash, G., de Salas, M. F., Griffiths, B., Tilbrook, B., Poisson, A., and Hallegraeff, G. M.: Shifts in geographic distributions of calcification morphotypes of the coccolithophorid Emiliania huxleyi in the Southern Ocean during 
2001-2006, Mar. Ecol. Prog. Ser., 348, 47-58, 2007.

DeLille, B., Harlay, J., Zondervan, I., Jacquet, S., Chou, L., Wollast, R., Bellerby, R. G. J., Frankignoulle, M., Borges, A. V., Riebesell, U., and Gattuso, J. P.: Response of primary production and calcification to changes of $p \mathrm{CO}_{2}$ during experimental blooms of the coccolithophorid Emiliania huxleyi, Global Biogeochem. Cy., 19, GB2023, doi:10.1029/2004GB002318, 2005.

Denman, K., Hofmann, E., and Marchant, H.: Marine biotic responses and feedbacks to environmental change and feedbacks to climate, in: Climate Change 1995, edited by: Houghton, J. T., Meira Filho, L. G., Callander, B. A., et al., The Science of Climate Change, Cambridge University Press, 1996.

Denman, K. L., Brasseur, G., Chidthaisong, A., Ciais, P., Cox, P. M., Dickinson, R. E.,Hauglustaine, D., Heinze, C., Holland, E., Jacob, D., Lohmann, U., Ramachandran, S., da Silva Dias, P. L., Wofsy S. C., and Zhang, X.: Couplings Between Changes in the Climate System and Biogeochemistry, in: Climate Change 2007: The Physical Science Basis. Contribution of Working Group I to the Fourth Assessment Report of the Intergovernmental Panel on Climate Change, edited by: Solomon, S., Qin, D., Manning, M., Chen, Z., Marquis, M., Averyt, K. B., Tignor, M., and Mille, H. L., Cambridge University Press, Cambridge, UK, 2007.

Dilling, L., Doney, S. C., Edmonds, J., Gurney, K. R., Harriss, R., Schimel, D., Stephens, B., and Stokes, G.: The role of carbon cycle observations and knowledge in carbon management, Ann. Rev. Env. Resour., 28, 521-558, doi:10.1146/annurev.energy.28.011503.163443, 2003.

Doney, S. C., Bullister, J. L., and Wanninkhof, R.: Climatic variability in upper ocean ventilation diagnosed using chlorofluorocarbons, Geophys. Res. Lett., 25, 1399-1402, 1998.

Doney, S. C., Lindsay, K., Caldeira, K., Campin, J.-M., Drange, H., Dutay, J.-C., Follows, M., Gao, Y., Gnanadesikan, A., Gruber, N., Ishida, A., Joos, F., Madec, G., Maier-Reimer, E., Marshall, J. C., Matear, R. J., Monfray, P., Mouchet, A., Najjar, R., Orr, J. C., Plattner, G.- K., Sarmiento, J., Schlitzer, R., Slater, R., Totterdell, I. J., Weirig, M.-F., Yamanaka, Y., and Yool, A.: Evaluating global ocean carbon models: the importance of realistic physics, Global Biogeochem. Cy., 18, GB3017, doi:10.1029/2003GB002150, 2004.

Doney, S. C., Lindsay, K., Fung I., and John, J.: Natural variability in a stable 1000 year coupled climate-carbon cycle simulation, $\mathrm{J}$. Climate, 19, 3033-3054, 2006.

Doney, S. C., Yeager, S., Danabasoglu, G., Large, W. G., and McWilliams, J. C.: Mechanisms governing interannual variability of upper ocean temperature in a global hindcast simulation, J. Phys. Oceanogr., 37, 1918-1938, 2007.

Duce, R. A. and Tindale, N. W.: The atmospheric transport of iron and its deposition in the ocean, Limnol. Oceanogr., 36, 17151726, 1991.

Dunne, J. A., Saleska, S. R., Fischer, M. L., and Harte, J.: Integrating experimental and gradient methods in ecological climate change research, Ecology, 85 904-916, 2004.

Edwards, R. and Sedwick, P.: Iron in East Antarctic snow: Implications for atmospheric iron deposition and algal production in Antarctic waters. Geophys. Res. Lett., 28, 3907-3910, 2001.

Falkowski, P. G. and LaRoche, J.: Acclimation to spectral irradiance in algae, J. Phycol., 27, 8-14, 1991.

Falkowski P. G., Barber, R. T., and V. Smetacek, V.: Biogeochemical controls and feedbacks on ocean primary production, Sci- ence, 281, 200-206, 1998.

Falkowski, P. G., Katz, M. E., Knoll, A. H., Quigg, A., Raven, J. A., Schofield, O., and Taylor, F. J. R.: The Evolution of Modern Eukaryotic Phytoplankton, Science 305, 354, doi:10.1126/science.1095964, 2004.

Feller, G., Ellis-Evans, J. C., Deubert, C., and Connelly, D. P.: Regulation by low temperature of phytoplankton growth and nutrient uptake in the Southern ocean, Mar. Ecol. Prog. Ser., 219, 51-64, 2001.

Follows, M. J., Dutkiewicz S., Grant, S., and Chisholm, S. W.: Emergent Biogeography of Microbial Communities in a Model Ocean, Science, 1843-1846, 2007.

Friedlingstein, P., Cox, P., Betts, R., Bopp, L., von Bloh, W., Brovkin, V., Cadule, S. Doney, M. Eby, I. Fung, G. Bala, J. John, C. Jones, F. Joos, T. Kato, P., Kawamiya, M., Knorr, W., Lindsay, K., Matthews, H. D., Raddatz, T., Rayner, P., Reick, C., Roeckner, E., Schnitzler, K.-G., Schnur, R., Strassmann, K., Weaver, A. J., Yoshikawa, C., and Zeng, N.: Climate-carbon cycle feedback analysis: Results from the C4MIP model intercomparison, J. Climate, 19(14), 3337-3353, 2006.

Fung, I. Y., Meyn, S. K., Tegen, I., Doney, S. C., John, J. G., and Bishop, J. K. B.: Iron supply and demand in the upper ocean, Global Biogeochem. Cy., 14, 697-700, 2000.

Fung, I., Doney, S. C., Lindsay, K., and John, J.: Evolution of carbon sinks in a changing climate, Proc. Nat. Acad. Sci. (USA), 102, 11 201-11 206, doi:10.1073/pnas.050494910, 2005.

Gibbs, S.J., Bown, P.R., Sessa, J.A., Bralower, T.J. and Wison, P.A.: Nannoplankton extinction and origination across the Paleocene-Eocene Thermal Maximum, Sceince, 314, 17701773, doi:10.1126/science.1133902, 2006.

Gille, S. T.: Warming of the Southern Ocean since the 1950s. Science, 295, 5558, 1275-1277, 2002.

Gordon, L. I., Codispoti, L. A., Jennings, J. C., Millero, F. J., Morrison, J. M., and Sweeney, C.: Seasonal evolution of hydrographic properties in the Ross Sea, Antarctica, 1996-1997, Deep Sea Res. II, 47, 3095-311, 2000.

Harrison, P. J., Waters, R. E., and Taylor, F. J. R.: A broad spectrum artificial seawater medium for coastal and open ocean phytoplankton, J. Phycol., 16, 28-35, 1980.

Hiscock, M. R., Marra, J., Smith, W. O., Barber, R. T.: Primary productivity and its regulation in the Pacific Sector of the Southern Ocean, Deep Sea Res. II, 50, 533-558, 2001.

Hutchins, D., Sedwick, P., DiTullio, G., Boyd, P., Quéguiner, B., Griffiths, B.F., and Crossley, C.: Control of phytoplankton growth by iron and silicic acid availability in the subantarctic Southern Ocean: Experimental results from the SAZ Project, J. Geophys. Res., 106, 31 559-31 572, 2001.

Iglesias-Rodriguez, M. D., Brown, C. W., Doney, S. C., Kleypas, J., Kolber, D., Kolber, Z., Hayes, P. K., and Falkowski, P. G.: Representing key phytoplankton functional groups in ocean carbon cycle models: coccolithophores, Global Biogeochem. Cycles, 16, 1100, doi:10.1029/2001GB001454, 2002.

Iglesias-Rodriguez, M. D., Schofield, O. M., Batley, J., Medlin L. K., and Hayes, P. K.: Intraspecific genetic diversity in the marine coccolithophore Emiliania huxleyi (Prymnesiophyceae): The use of microsatellite analysis in marine phytoplankton population studies, J. Phycol. 42, 526-536, 2006.

Iglesias-Rodriguez, M. D., Halloran, P. R., Rickaby, R. E. M., Hall, I. R., Colmenero-Hidalgo, E., Gittins, J. R., Green, D. R. 
H., Tyrrell, T., Gibbs, S. J., von Dassow, P., Rehm, E., Armbrust, E. V., and Boessenkool, K. P.: Phytoplankton Calcification in a High- $\mathrm{CO}_{2}$ World, Science 320, 336, doi: $10.1126 /$ science.1154122, 2008.

Kaplan, A., Schwarz, R., Lieman-Hurwitz, J., and Reinhold L.: Physiological and Molecular Aspects of the Inorganic CarbonConcentrating Mechanism in Cyanobacteria, Plant Physiol., 97, 851-855, 1991.

Kepner, R. L. and Pratt, J. R.: Use of Fluorochromes for Direct Enumeration of Total Bacteria in Environmental-Samples - Past and Present, Microbiol. Rev. 58, 603-15, 1994.

Langer G., Geisen, M., Baumann, K.-H, Klaus, J., Riebesell, U., Thoms, S., and Young, J. R.: The response of Calcidiscus leptoporus and Coccolithus pelagicus to changing carbonate chemistry of seawater, Geophys. Res. Abst., 8, 05161, 2006a.

Langer G., Geisen M., Baumann K.-H., Klaus, J., Riebesell, U., Thoms, S., and Young, J. R.: Species-specific responses of calcifying algae to changing seawater carbonate chemistry, Geochem. Geophys. Geosyst., 7, Q09006, doi:10.1029/2005GC001227, 2006b.

Legendre L. and Rivkin, R. B.: Integrating functional diversity, food web processes, and biogeochemical carbon fluxes into a conceptual approach for modeling the upper ocean in a high- $\mathrm{CO}_{2}$ world, J. Geophys. Res., 110, C09S17, doi:10.1029/2004JC002530, 2005.

Le Quéré C., Harrison, S. P., Prentice, C., Buitenhuis, E. T., Aumont, O., Bopp, L., Claustre, H., Cotrim Da Cunha, L., Geider, R., Giraud, X., Klaas, C., Kohfeld, K., Legendre, L., Manizza, M., Platt, T., Rivkin, R. B., Sathyendranath, S., Uitz, J., Watson, A. J., and Wolf-Gladrow, D.: Ecosystem dynamics based on phytoplankton functional types for global ocean biogeochemistry models, Global Change Biol. 11, 2016-2040, 2005.

Le Quéré, C., R“odenbeck, C., Buitenhuis, E. T. Conway, T. J. Langenfelds, R. Gomez, A. Labuschagne, C. Ramonet, M. Nakazawa, T. Metzl N., Gillett, N. and Heimann M.: Saturation of the Southern Ocean $\mathrm{CO}_{2}$ Sink Due to Recent Climate Change, Science, 316, 1735-1738, doi:10.1126/science.1136188, 2007.

Levitus, S., Antonov, J. I., and Boyer, T. P: Warming of the World Ocean, 1955-2003, Geophys. Res. Lett., 32, L02604, doi:10.1029/2004GL021592, 2005.

Litchman, E., Klausmeier, C. A., Miller, J. R., Schofield, O. M., and Falkowski, P. G.: Multinutrient, multi-group model of present and future oceanic phytoplankton communities, Biogeosciences, 3, 585-606, http://www.biogeosciences.net/3/585/2006/. 2006,

Lovenduski, N. S., Gruber, N., Doney S. C., and Lima, I. D.: Enhanced $\mathrm{CO}_{2}$ outgassing in the Southern Ocean from a positive phase of the Southern Annular Mode, Global Biogeochem. Cy., 21, GB2026, doi:10.1029/2006GB002900, 2007.

MacIntyre, H. L. and Cullen, J. J.: Using cultures to investigate the Physiological ecology of Microalgae, in: Algal Culturing Techniques, edited by: Andersen, R. A., Elsevier, Amsterdam, 287326, 2005.

Mahowald, N. M. and Luo, C.: A less dusty future?, Geophys. Res. Lett., 30(17), 1903, doi:10.1029/2003GL017880, 2003.

Mahowald, N. M., Baker, A. R., Bergametti, G., Brooks, N., Duce, R. A., Jickells, T. D., Kubilay, N., Prospero, J. M., and Tegen, I.: Atmospheric global dust cycle and iron inputs to the ocean, Global Biogeochem. Cy., 19, GB4025, doi:10.1029/2004GB002402, 2005.
Maldonado, M. T. and Price, N. M.:. Influence of N substrate on Fe requirements of marine centric diatoms, Mar. Ecol. Prog. Ser, 141, 161-172, 1996.

Maldonado, M. T. and Price, N. M.: Utilization of iron bound to strong organic ligands by plankton communities in the subarctic Pacific Ocean. Deep-Sea Res. II, 46, 2447-2473, 1999.

Margalef, R: Life-forms of phytoplankton as survival alternatives in an unstable environment, Oceanologia Acta, 1, 493-509, 1978.

Martin, C. L. and Tortell, P. D.: Bicarbonate transport and extracellular carbonic anhydrase activity in Bering Sea phytoplankton assemblages: Results from isotope disequilibrium experiments, Limnol. Oceanogr. 51, 2111-2121, 2006.

Matear, R. and Hirst, A. C.: Climate change feedback on the future oceanic $\mathrm{CO}_{2}$ uptake. Tellus 51, 722-733, 1999.

Measures C. I. and Vink, S.: Dissolved Fe in the upper waters of the Pacific sector of the Southern Ocean, Deep Sea Res. II, 48, 3913-3941, 2001.

Medlin, L. K.: Genetic Variability and phytoplankton species, Chapter 34, IOC Workshop report \#, 142, 257-265, 1994.

Medlin, L. K., Barker, G. L. A., Wrieden, S., and Vaulot, D.: Genetic characterisation of Emiliania huxleyi (Haptophyta), J. Mar. Syst., 9, 13-31, 1996.

Merico, A., Tyrrell, T., Brown, C. W., Groom, S. B., and Miller, P. I.: Analysis of satellite imagery for Emiliania huxleyi blooms in the Bering Sea before 1997, Geophys. Res. Lett., 30, 1337-1340, 2003.

Moline, M. A., Claustre, H., Frazer, T. K., Schofield, O., and Vernet, M.: Alteration of the food web along the Antarctic Peninsula in response to a regional warming trend, Global Change Biol., 10, 1973-1980, doi:10.1111/j.1365-2486.2004.00825, 2004.

Moran, X. A. G., Sebastián, M., Pedros-Alio, C., and Estrada, M.: Response of Southern ocean phytoplankton and bacterioplankton production to short-term experimental warming, Limnol. Oceanogr., 51, 1791-1800, 2006.

Najjar, R. G., Jin, X., Louanchi, F., Aumont, O., Caldeira, K., Doney, S. C., Dutay, J.-C., Follows, M., Gruber, N., Joos, F., Lindsay, K., Maier-Reimer, E., Matear, R. J., Matsumoto, K., Monfray, P., Mouchet, A., Orr, J. C., Plattner, G. K., Sarmiento, J. L., Schlitzer, R., Slater, R.D., Weirig, M.-F., Yamanaka, Y., and Yool, A.: Impact of circulation on export production, dissolved organic matter and dissolved oxygen in the ocean: Results from Phase II of the Ocean Carbon-cycle Model Intercomparison Project (OCMIP-2), Global Biogeochem. Cy., 21, GB3007, doi:10.1029/2006GB002857, 2007.

Nelson, D. M., Brzezinski, M. A., Sigmon, D. E., and Franck, V. M.: A seasonal progression of Si limitation in the Pacific sector of the Southern Ocean, Deep-Sea Res. II, 48, 3973-3995, 2001.

Nodder, S. D., Boyd, P. W., Chiswell, S. M., Pinkerton, M. H., Bradford-Grieve, J. M., Greig, M. J. N.: Temporal coupling between surface and deep ocean biogeochemical processes in contrasting subtropical and subantarctic water masses, southwest Pacific Ocean, J. Geophys. Res., 110, C12017, doi:10.1029/2004JC002833, 2005.

Peterson, W. T. and Keister, J. E.: Interannual variability in copepod community composition at a coastal station in the northern California Current: A multivariate approach, Deep-Sea Res. II, 50, 2499-2517, 2003.

Price, N. M., Harrison, G. I., Hering, J. G., Hudson, R. J., Nirel, P. M. V., Palenik, B., and Morel, F. M. M.: Preparation and chem- 
istry of the artificial algal culture medium Aquil, Biol. Oceanogr., 6, 443-461, 1988.

Quigg, A., Finkel, Z. V., Milligan, A. J., Wyman, K., Falkowski, P. G., and Morel, F. M. M.: The evolutionary inheritance of elemental stoichiometry in marine phytoplankton, Nature, 425 , 291-294, 2003.

Raitsos, D. E., Lavender, S. J., Maravelias, C.D., Haralambous, J., Richardson, A.J., and P.C. Reid, P.C.: Identifying phytoplankton functional groups from space: an ecological approach. Limnol. Oceanogr., in press, 2008.

Raven, J. A., Evans, M. C. W., and Korb, R. E.: The role of trace metals in photosynthetic electron transport in $\mathrm{O}_{2}$-evolving organisms, Photosynth. Res., 60, 111-149, 1999.

Reynolds, C. S.: The Ecology of Freshwater Phytoplankton, 397 pp., Cambridge University Press, Cambridge, UK, 1984.

Riebesell, U., Zondervan, I., Rost, B., Tortell, P. D., Zeebe, R. E., and Morel, F. M. M.: Reduced calcification of marine plankton in response to increased atmospheric $\mathrm{CO}_{2}$, Nature, 407, 364-367, 2000.

Riebesell, U., Schulz, K. G., R. G. J. Bellerby, R. G. J., Botros, M., Fritsche, P., Meyerho"fer, M.,. Neill, N., Nondal, G., Oschlies, A., Wohlers, J., and Zöllner., E: Enhanced biological carbon consumption in a high $\mathrm{CO}_{2}$ ocean, Nature, 450, 545-546, doi:10.1038/nature06267, 2007.

Ringbom, A.: Complexation in Analytical Chemistry, New York: Interscience, 1963.

Rost, B., Riebesell, U., and Burkhardt, S.: Carbon acquisition of bloom-forming marine phytoplankton, Limnol. Oceanogr., 48, 55-67, 2003

Russell, J. L., Dixon, K. W., Gnanadesikan, A., Stouffer, R. J., and Toggweiler, J. R.: The Southern Hemisphere westerlies in a warming world: propping open the door to the deep ocean, J. Climate, 19, 6382-6390, 2006.

Saito, M. A., Sigman, D. M., and Morel, F. M. M: The bioinorganic chemistry of the ancient ocean: the co-evolution of cyanobacterial metal requirements and biogeochemical cycles at the Archean-Proterozoic boundary?, Inorg. Chim. Acta, 356, 308318, 2003.

Sarmiento, J. L.: Atmospheric $\mathrm{CO}_{2}$ stalled, Nature, 365, 697-698, 1993.

Sarmiento, J. L., Hughes, T. M. C., Stouffer, R. J., and Manabe, S.: Simulated response of the ocean carbon cycle to anthropogenic climate warming, Nature, 393, 245-249, 1998.

Sarmiento, J. L., Slater, R. Barber, R., Bopp, L., Doney, S. C., Hirst, A. C., Kleypas, J., Matear, R., Mikolajewicz, U., Monfray, P., Soldatov, V., Spall, S. A., and Stouffe, R.: Response of ocean ecosystems to climate warming, Global Biogeochem. Cy., 18, GB3003, doi:10.1029/2003GB002134, 2004.

Sedwick, P. N., Garcia, N. S., Riseman, S. F., Marsay, C. M., and DiTullio, G. R.: Evidence for high iron requirements of colonial Phaeocystis antarctica at low irradiance, Biogeochemistry, 83, 83-97, doi:10.1007/s10533-007-9081-7, 2007.

Sherlock, V., Pickmere, S., Currie, K., Hadfield, M., Nodder, S., and Boyd, P. W.: Predictive accuracy of temperature-nitrate relationships for the oceanic mixed layer of the New Zealand region, J. Geophys. Res., 112, C06010, doi:10.1029/2006JC003562, 2007.
Smayda, T. J., Borkman, D. G., Beaugrand, G., and Belgrano, A. G.: Ecological effects of climate variation in the North Atlantic: Phytoplankton, in: Ecological Effects of Climatic Variations in the North Atlantic, edited by: Stenseth, N. C., Ottersen, G., Hurrell, J., and Belgrano, A., Oxford Univ. Press., UK, 48-58, 2005.

Smetacek, V. and Nichol, S.: Polar ocean ecosystems in a changing world, Nature, 437, 362-368, 2005.

Smith, T. M. and Reynolds, R. W.: A global merged land and sea surface temperature reconstruction based on historical observations (1880-1997), J. Climate, 18, 2021-2036, 2005.

Takeda, S.: Influence of iron availability on nutrient consumption ratio of diatoms in oceanic waters, Nature, 393, 774-777, 1998.

Tilzer, M. M., Elbrächter, M., Gieskes, W. W., and Beese, B.: Light-Temperature interactions in the control of photosynthesis in Antarctica phytoplankton, Polar Biol., 5, 105-111, 1986.

Timmermans, K. R., Gerringa, L. J. A., de Baar, H. J. W., van der Wagt, B., Veldhuis, M. J. W., de Jong, J. T. M., and Croot, P. L.: Growth rates of large and small Southern ocean diatoms in relation to the availability of iron in natural seawater, Limnol. Oceanogr., 46, 260-266, 2001.

Tortell, P. D., DiTullio, G. R., Sigman, D. M., and Morel, F. M. M.: $\mathrm{CO}_{2}$ effects on taxonomic composition and nutrient utilization in an Equatorial Pacific phytoplankton assemblage, Mar. Ecol. Progr. Ser., 236, 37-43, 2002.

Tortell, P. D., Martin and C. L., and Corkum, M. E.: Inorganic carbon uptake and intracellular assimilation by subarctic Pacific phytoplankton assemblages, Limnol. Oceanogr. 51, 2102-2110, 2006.

Tortell, P. D., Payne, C. D., Li, Y., Trimborn, S., Rost, B., Smith, W. O., Riesselman, C., Dunbar R. B., Sedwick, P., and G. R. DiTullio, G.R.: $\mathrm{CO}_{2}$ sensitivity of Southern Ocean phytoplankton, Geophys. Res. Lett., 35, L04605, doi.org/10.1029/2007GL032583, 2008.

Tortell, P.D., Rost, B., Strzepek, R., Boyd, P.W., and DiTullio G.: Uptake and assimilation of inorganic carbon by Southern Ocean phytoplankton, Limnol. Oceanogr., in press, 2008.

Trenberth, K. E., Jones, P. D., Ambenje, P., Bojariu, R., Easterling, D., Klein, A., Tank, T., Parker, D., Rahimzadeh, F., Renwick, J. A., Rusticucci, M., Soden, B., and Zhai, P.: Observations: Surface and Atmospheric Climate Change, in: Climate Change 2007: The Physical Science Basis, Contribution of Working Group I to the Fourth Assessment Report of the Intergovernmental Panel on Climate Change, edited by: Solomon, S., Qin, D., Manning, M., Chen, Z., Marquis, M., Averyt, K. B., Tignor, M., and Miller, H. L., Cambridge University Press, Cambridge, United Kingdom and New York, NY, USA, 2007.

Walther, G.-R.: Tackling ecological complexity in climate impact research, Science, 315, 606-607, 2007.

Westall, J. C., Zachary, J. L., and Morel, F. M. M.: MINEQL: A computer program for the calculation of chemical equilibrium composition of aqueous systems, (Department of Civil engineering, MIT, Cambridge, Massachusetts), 1976.

Westberry, T. K. and Siegel, D. A.: Spatial and temporal distribution of Trichodesmium blooms in the world's oceans, Global Biogeochem. Cy., 20, GB4016, doi:10.1029/2005GB002673, 2006. 